\title{
Multi-isotopic study of diet and mobility in the northeastern Nile Delta
}

\author{
Chris Stantis ${ }^{1,2}$ (D) Arwa Kharobi $^{1,3}$ (D) Nina Maaranen ${ }^{1}$ (D) $\cdot$ Colin Macpherson $^{4}$ (D) Manfred Bietak $^{5}$ (D) \\ Silvia Prell ${ }^{5}$ (D) Holger Schutkowski ${ }^{1}$ (D)
}

Received: 30 October 2020 / Accepted: 12 April 2021 / Published online: 1 June 2021

(C) The Author(s) 2021

\begin{abstract}
The origin of the Hyksos dynasty (c. 1638-1530 BCE) is thought to be rooted in the Near East given the architectural features and burial customs present at the site of Tell el-Dab ${ }^{c}$ a, identified as the capital of Hyksos rule in the Eastern Delta of Egypt. We expand previous ${ }^{87} \mathrm{Sr} /{ }^{86} \mathrm{Sr}$ research on the site's cemetery assemblage using a multi-isotopic methodology: oxygen $\left(\delta^{18} \mathrm{O}\right)$ and carbon $\left(\delta^{13} \mathrm{C}_{\text {carb }}\right)$ stable isotopes from the carbonate portion of tooth enamel $(n=75)$, along with collagen $\left(\delta^{13} \mathrm{C}_{\text {coll }}, \delta^{15} \mathrm{~N}\right)$ analysis of dentine and bone $(n=31)$. Pairing $\delta^{18} \mathrm{O}$ with previous ${ }^{87} \mathrm{Sr} /{ }^{86} \mathrm{Sr}$ data identifies $60 \%$ of the cohort as non-locals $(45 / 75)$. Although there were a greater proportion of non-local females $(24 / 30,80 \%)$ compared to males $(10 / 20,50 \%)$, there were no significant differences between the sexes in $\delta^{13} \mathrm{C}_{\text {carb }}$ or $\delta^{18} \mathrm{O}_{\text {carb }}$ values. There were no spatial patterns regarding the three cemetery sites, nor any observable patterns regarding where non-locals were interred in the largest excavated cemetery, Area A/II. Both first-generation immigrants and individuals from the northeastern Nile Delta were buried following elite Asiatic burial customs, suggesting continuation of foreign burial culture. All collagen showed poor preservation; $\delta^{13} \mathrm{C}_{\text {coll }}$ and $\delta{ }^{15} \mathrm{~N}$ analysis were not possible. $\delta^{13} \mathrm{C}_{\text {carb }}$ showed no significant difference between locals and non-local diet, although non-locals at Tell el-Dab ${ }^{c}$ a did eat a broader variety of foods as a group, suggested by a wider $\delta^{13} \mathrm{C}_{\text {carb }}$ range (-13.5 to $-9.6 \%$ in non-locals compared to locals' -12.1 to $-10.3 \%$ ). If there is a difference in food culture between immigrants and native Egyptians, it was not observable using isotopic analyses.
\end{abstract}

Keywords Migration $\cdot$ Diet $\cdot$ Second Intermediate Period $\cdot$ Middle Kingdom $\cdot$ Middle Bronze Age $\cdot$ Levant

\section{Introduction}

During the so-called Hyksos Period and its prelude (c. 17501530 BCE), Egypt was confronted with two unprecedented phenomena: the migration of a substantial foreign population into the Eastern Delta from the late Middle Kingdom onwards

Chris Stantis

cstantis@bournemouth.ac.uk

1 Department of Archaeology and Anthropology, Bournemouth University, Poole, United Kingdom

2 Department of Anthropology, National Museum of Natural History, Smithsonian Institution, Washington, DC, USA

3 PACEA - De la Préhistoire à l'Actuel: Culture, Environnement et Anthropologie, Université de Bordeaux, Bordeaux, France

4 Department of Earth Sciences, Durham University, Durham, United Kingdom

5 Austrian Academy of Sciences, Vienna, Austria and, probably as a result, the rule of a foreign dynasty over Egypt's north during the Second Intermediate Period (Bietak 2010a). Arriving to Egypt most likely as traders, craftsmen, sailors, and expedition leaders, they created a hybrid EgyptoLevantine culture in one of the most important trade centers and harbor cities of its time, Tell el-Dab a, which later became the capital of the 15th Dynasty Hyksos kings (Fig. 1). From the archaeological evidence, these immigrants clearly had their roots in the Near East. However, their exact geographical origin, the degree of their cultural and ethnic homogeneity, the reasons for their migration to Egypt, and the means by which they assumed political control are still partly unclear (Baines 1996; Bietak 1996).

Stable isotopes, especially those that can identify individuals who spent part of their lives outside of the location where they were buried, can contribute data for identifying first-generation immigration. Stable isotope analyses are powerful tools in archaeological sciences, used in past archaeological studies in Egypt and Sudan for the investigation of human diet (Dupras 1999; 
Fig. 1 Location of Tell el-Dab ${ }^{\mathrm{a}} \mathrm{a}$ in northern Egypt

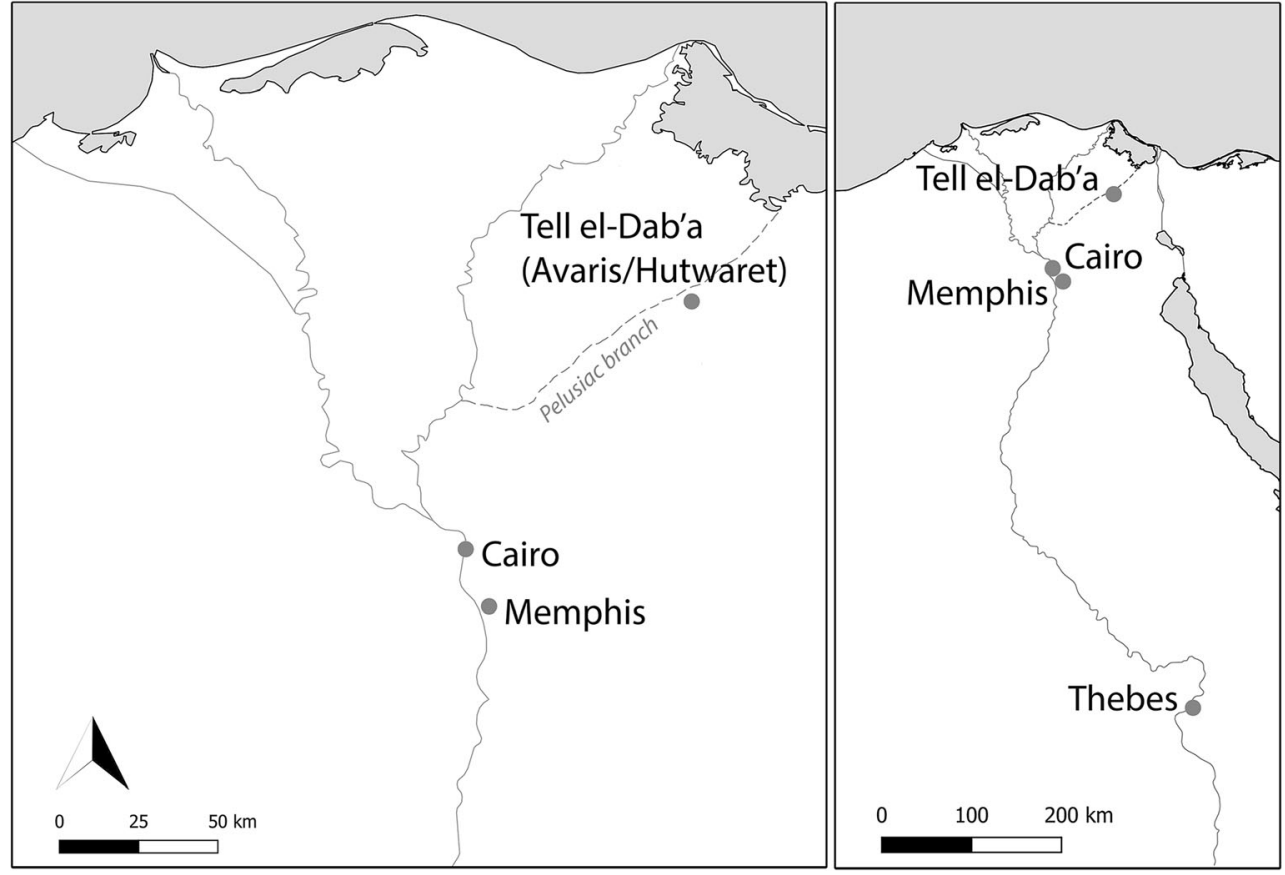

Eerkens et al. 2018) and mobility (Buzon and Bowen 2010; Buzon et al. 2007; Schrader et al. 2019; Stantis et al. 2020).

In addition to 'traditional' isotopes for mobility, food choices might also pinpoint first-generation immigrants if they maintained their homeland cuisine and if their homeland cuisine is sufficiently isotopically different from local diet. This line of research relates to dietary acculturation, the process of consuming an increasing proportion of foods native to the host country (Satia-Abouta et al. 2002). Dietary acculturation is studied in modern populations to understand the dynamics of cultural identity and assimilation, as well as its effects on lifestyle risk factors and nutrition (Dondero et al. 2018; Peters et al. 2020; Ramírez et al. 2018). From an archaeological context, dietary acculturation can be limited due to an inability to identify firstgeneration immigrants and compare them to the rest of the population. Isotopic identification of first-generation immigrants grants opportunity to investigate this phenomenon and consider the potential causes and consequences of food choice and availability in immigrants.

In this paper, we address four major questions:

1. Does the oxygen stable isotope data agree with the strontium data for who is non-local?

2. Are there any patterns in migration regarding burial location, the sexes, or time periods?

3. Are the non-locals eating a significantly different diet from those who grew up in the region?
4. Are there any trends in isotopic values associated with those buried in the most elite burial customs or those buried as servants in front of these elite tombs?

\section{Bronze Age Diet in Egypt}

Isolating Dynastic Egyptian dietary and subsistence strategies by major chronological periods (e.g., Middle Kingdom, Second Intermediate Period) can be difficult, but we can broadly describe major food groups on the Bronze Age menu. Much of the information about the types of foods consumed in ancient Egypt are derived from figurative depictions of feasts (Alcock 2006) as well as papyri recording extracts of the economic systems of the times (Allen and Hekanakhte 2002). The depictions of feasts contain bias both as representing only the upper classes as well as being idealized depictions of these special events (Harrington et al. 2016). Archaeological evidence of foods from middens and graves also provide insight (Caracuta et al. 2018; Kemp et al. 1994; Moens and Wetterstrom 1988).

The core of Dynastic Egyptian diet was $\mathrm{C}_{3}$ plants: bread made from wheat, especially emmer (Triticum dicoccon), leafy vegetables such as onions and leeks (Allium spp.), and pulses such as lentils, peas, and chickpeas. Beer from barley (Hordeum vulgare) was an everyday beverage for all socioeconomic groups (Farag et al. 2019; Riehl 2019; Samuel 1996). Wine and olive oil were major imports from the Levant for upper class consumption with increased demands from the Middle Kingdom (Marcus 2007), though some wine 
had been produced locally from the Early Dynastic Period (Arnold et al. 1995; Cohen 2018; David 1999; Murray 1999).

Some prominent $\mathrm{C}_{4}$ sedges of the Cyperus genus were collected for both human consumption and as fodder ( $\mathrm{Li}$ et al. 1999). Since pre-Dynastic periods, tiger nuts (Cyperus esculentus) and yellow nut grass (Cyperus rotundus) were collected as wild plants or cultivated as crops (Fahmy et al. 2013; Murray 2000; Negbi 1992). Roots and stems of papyrus (Cyperus papyrus) were also edible (Crawford 2007).

Domesticated animals such as ovicaprines, cattle, pigs, and fowl were sources of meat and some dairy products, although animal flesh was rarely consumed by those of lower socioeconomic status (Alcock 2006). Freshwater fish seem to have been a consistent source of food for the lower classes along the Nile through Pharaonic times, although some priesthoods and the upper classes avoided consumption of fish for religious purposes at different time periods (Darby et al. 1977). Invertebrate consumption (e.g., shellfish), whether freshwater, marine, or terrestrial, is evidenced in middens during the Hellenistic Period/Late Antiquity (Morand 2020), though invertebrate consumption during the Dynastic Periods appear to be of minor importance judging from the scattered shell of edible species found at a few Egyptian sites (Ablamowicz et al. 2004; Castel 1988; Castel et al. 1999).

\section{Stable isotope background}

The stable isotopes used in this study (carbon, nitrogen, and oxygen) are expressed as a ratio of heavy versus light isotopes and is reported using the delta notation $(\delta): \delta=\left[\left(R_{\text {sample }} /\right.\right.$ $\left.\left.R_{\text {standard }}-1\right) \times 1000\right]$ where $R$ is ${ }^{13} \mathrm{C} /{ }^{12} \mathrm{C},{ }^{15} \mathrm{~N} /{ }^{14} \mathrm{~N}$, or ${ }^{18} \mathrm{O} /{ }^{16} \mathrm{O}$ in this study (Hoefs 2009; Sharp 2017).

\section{$\delta^{18} 0$}

Oxygen stable isotope analysis $\left(\delta^{18} \mathrm{O}\right)$ is a common method of investigating individual movement (Chenery et al. 2010; Müldner et al. 2011; Prowse et al. 2007). The main intake of oxygen atoms into the body is through drinking water (Bryant and Froelich 1995; Longinelli 1984; Luz and Kolodny 1989), and the difference in proportions between ${ }^{18} \mathrm{O}$ and ${ }^{16} \mathrm{O}$ is dependent largely on the location's climate (e.g., mean temperature, altitude, proximity to coast) from which the drinking water is sourced (Daux et al. 2008; Pederzani and Britton 2018). Oxygen can be analyzed from two functional groups within hydroxyapatite: the phosphate $\left(-\mathrm{PO}_{4}\right)$ or the carbonate $\left(-\mathrm{CO}_{3}\right)$ group. The phosphate group is more tightly bound and less susceptible to diagenetic alterations (Chenery et al. 2012), but the stable isotope analysis of the structural carbonate ion also provides $\delta{ }^{13} \mathrm{C}_{\text {carbonate }}$ data for dietary information (Commendador et al. 2019; Gregoricka et al. 2020; King et al. 2013).

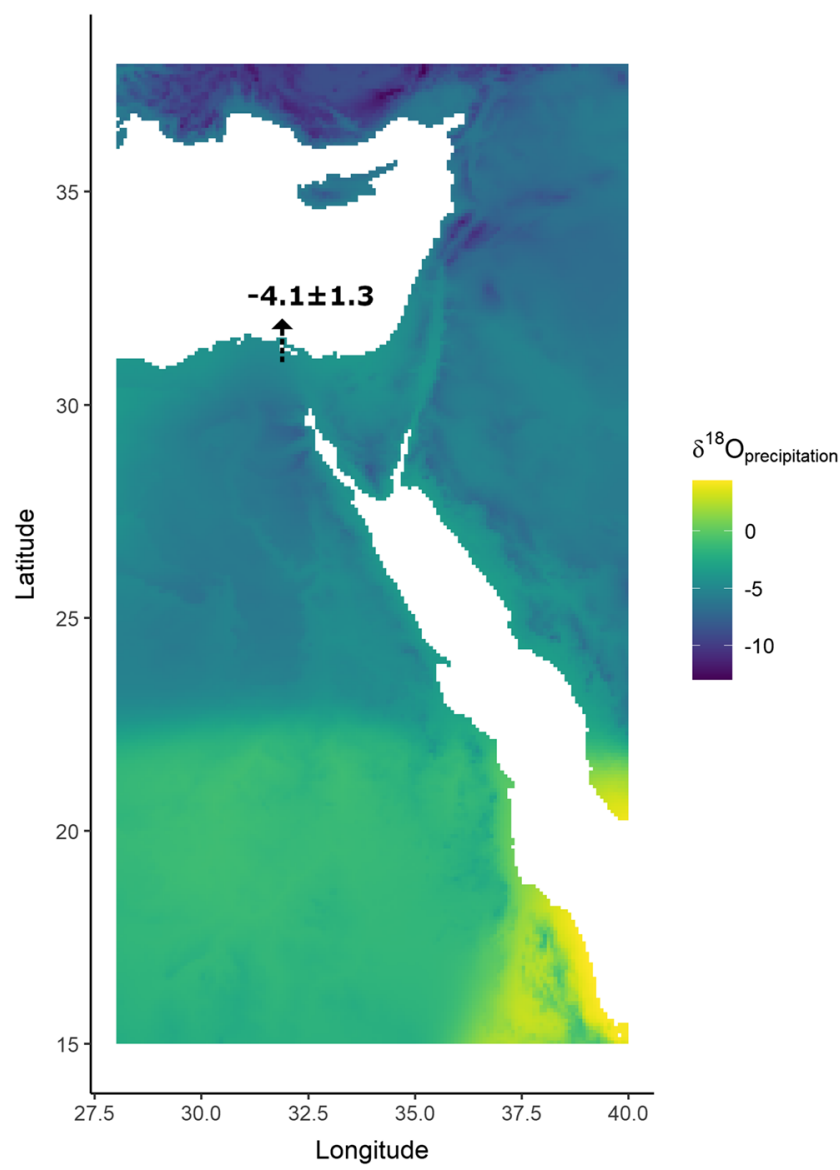

Fig. 2 Modern $\delta^{18} \mathrm{O}$ variation in annual mean precipitation across the wider region, with calculated $\delta^{18} \mathrm{O}$ annual precipitation values at Tell el-Dab ${ }^{c}$ a emphasized. Data from the Online Isotopes in Precipitation Calculator (Bowen 2018): https://wateriso.utah.edu/waterisotopes/ pages/data_access/oipc.html

In order to consider possible proxy values for the oxygen stable isotope values $\left(\delta^{18} \mathrm{O}_{\mathrm{dw}}\right)$, modern mean annual precipitation oxygen values across the region have been recorded (Bowen 2018; Bowen et al. 2013). When plotted (Fig. 2), variation is observable, especially to the south where it is hotter and more arid, and in cooler regions such as mountain ranges. Calculated annual mean oxygen values for Tell el$\mathrm{Dab}^{\mathrm{c}} \mathrm{a}$ are $-0.4 \pm 1.3 \%$ (1 SD) (Bowen 2018). Drinking water from the Nile River will be/have been a major contributor for oxygen values in human tissues and is potentially a better proxy than annual mean precipitation values. The modern $\delta^{18} \mathrm{O}$ value of the Nile, measured in Cairo, is $+2.8 \%$ o (Cockerton et al. 2013), which is believed to have shifted significantly since the 1960 s due to the building of the Aswan High Dam. Paleoclimatologists cannot state empirically the shift in values this has caused but some estimate the Nile River was $4 \%$ lower before the damming, which would place the northern Nile water around $-2.8 \%$ (Geirnaert and Laeven 1992). Groundwater values, however, might be more reflective of pre-damming values in the region. There are some environmental isotope studies providing values from 
groundwater and well sources in the northeastern Nile Delta between the Damietta Branch and Ismailia Canal (Ahmed et al. 2013; Al-Gamal et al. 2018; Eissa et al. 2019; Gomaah et al. 2016; Hamza et al. 1987; Hassan et al. 2020). Groundwater and well samples from these studies $(n=181)$ display an average value of $2.23 \pm 1.43 \%$ o ( $1 \mathrm{SD}$ ).

Values of $\delta^{18} \mathrm{O}$ in tooth enamel can be converted back to the estimated drinking water values using a regression equation (Daux et al. 2008) but it must be emphasized that culturally mediated alterations to the drinking water (e.g., "brewing and stewing") would have shifted imbibed $\delta^{18} \mathrm{O}$ values to more positive values compared to the original ingested water values (Brettell et al. 2012). Shifts in oxygen values between individuals can be difficult due to the multitude of variables affecting values, such as climate shifts (seasonal and over longer scales), individual mobility, dietary intake, and individual physiology (Tuross et al. 2017; Pederzani and Britton 2018). The difficulty of utilizing $\delta^{18} \mathrm{O}$ values for investigating human mobility in the Nile Valley has been noted by previous researchers (Buzon and Bowen 2010).

Although strontium $\left({ }^{87} \mathrm{Sr} /{ }^{86} \mathrm{Sr}\right)$ isotope analysis is limited along the Nile due to the homogenization of alluvium relied upon for crop growing (Stantis et al. 2019), the method has had some utility for identifying non-locals in the northeastern Nile Delta (Stantis et al. 2020). Coupling stable and strontium isotopic approach can ameliorate some of the weaknesses of each method when used in isolation.

\section{$\delta^{13} \mathrm{C}$ and $\delta^{15} \mathrm{~N}$}

Carbon and nitrogen stable isotopes are typically utilized as 'dietary isotopes'. The analysis of carbon and nitrogen stable isotopes is based on the principle that we build our body out of the food we eat and the water we drink, and that our tissues reflect these dietary inputs: that 'we are what we eat' (Ambrose and Krigbaum 2003; Hedges et al. 2007; Katzenberg 2008; Schoeninger 2010).

Most of the differences in carbon isotopic values $\left(\delta^{13} \mathrm{C}\right)$ between food webs arise from the varying $\delta^{13} \mathrm{C}$ values of autotrophs (Lee-Thorp et al. 1989; Sharp 2017). $\delta^{13} \mathrm{C}$ can be measured to differentiate between the consumption of terrestrial $\mathrm{C}_{3}$ plants and marine foods in past populations (DeNiro and Epstein 1978; Hoefs 2009; Lee-Thorp et al. 1989). Values of $\delta^{13} \mathrm{C}$ range between -33 and $-23 \%$ in terrestrial $C_{3}$ plants (Marshall et al. 2007) while $\mathrm{C}_{4}$ plants, such as tiger nuts and papyrus will display higher $\delta^{13} \mathrm{C}$ values than terrestrial $\mathrm{C}_{3}$ plants and largely overlap in values with marine autotrophs, between - 16 and - 9\%o (Fry et al. 1982; Keegan and DeNiro 1988; Schoeninger and DeNiro 1984).

Carbon stable isotopes in human body tissues can be analyzed from both the organic and mineral portions of bones and teeth: $\delta^{13} \mathrm{C}_{\text {collagen }}$, analyzed in tandem with $\delta^{15} \mathrm{~N}$, and $\delta^{13} \mathrm{C}_{\text {carbonate }}$ analyzed together with $\delta^{18} \mathrm{O}_{\text {carbonate }}$ (Sharp
2017). Analyzing carbon stable isotope values of these two tissues gives insight into different parts of the consumer's diet due to differences in fractionation factors between tissues (Hobson and Clark 1992; Tieszen et al. 1983). $\delta^{13} \mathrm{C}_{\text {collagen }}$ is largely representative of the protein portion of an individual's diet, while $\delta^{13} \mathrm{C}_{\text {carbonate }}$ reflects the isotopic composition of the whole diet (i.e., carbohydrates, lipids, and protein) (Ambrose and Norr 1993; Balasse et al. 2003; Jim et al. 2004; Lee-Thorp et al. 1989; Passey et al. 2005; Tieszen and Fagre 1993).

Examining nitrogen stable isotope values $\left(\delta^{15} \mathrm{~N}\right)$ in bone collagen allows researchers to understand an organism's trophic level due to a 3-5\%o stepwise enrichment between herbivores and the carnivores that prey upon them, with omnivores somewhere in between (Bocherens and Drucker 2003; Minagawa and Wada 1984; O'Connell et al. 2012; Perkins et al. 2014). There is also a stepwise enrichment of ${ }^{13} \mathrm{C}$ values between trophic levels but the enrichment is too small $(\sim 1 \%)$ to be easily observed except in controlled studies (Bocherens and Drucker 2003; DeNiro and Epstein 1978). Marine food webs tend to be more complex with higher trophic levels, causing higher $\delta^{15} \mathrm{~N}$ values in humans consuming marine foods (Richards and Hedges 1999; Stantis et al. 2016; Stantis et al. 2015).

By analyzing different tissues from adults, researchers can examine multiple portions of an individual's life (Lamb et al. 2014; Schroeder et al. 2009). The stable isotope ratios of bone collagen are representative of a person's diet during the last years of their life because bone is constantly remodeled (Hedges et al. 2007). Human teeth, however, do not remodel once formed (Hillson 1996) and so the examination of dentine collagen gives a "snapshot" of an individual's childhood diet (Beaumont et al. 2013a; Beaumont et al. 2013b).

\section{The site of Tell el-Dab`a}

Tell el-Dab ${ }^{\mathrm{c}} \mathrm{a}\left(30^{\circ} 47^{\prime} 14.64^{\prime \prime}, 31^{\circ} 49^{\prime} 16.68^{\prime \prime}\right)$ sits on the nowdefunct Pelusiac branch of the Nile in the northeastern Nile Delta region. This region is characterized by low plains of rich alluvial deposits with SW-NE belts of hills or geziras (Said 2017). During the Second Intermediate Period, several river channels formed a network around a gezira formed by aeolian sands on which sits the site of Tell el-Dab ${ }^{c}$ a (Dorner 1994; Tronchère et al. 2012).

The stratigraphy at Tell el-Dab ${ }^{c}$ a records over 500 years of occupation spanning the rise of the Hyksos (Bietak 1975; Bietak 1996; Bietak 2010a). Therefore, examination of the cemetery assemblages offers a direct assessment of these residents and of the timing and mechanisms of their ascent to rule. During the Middle Kingdom, a settlement was founded in the northeastern Nile Delta as an administrative center and harbor city that grew in power (Czerny 2001; Czerny 2015; Forstner-Müller 2007) to become the capital of the regional Hyksos Kingdom (the 15th Dynasty). It was largely 
abandoned around 1550 BCE following the campaigns of the southern Theban Kingdom (17th Dynasty) which sought to defeat the Hyksos rulers and found the New Kingdom (Bader 2013; Bietak 1979; Bietak 1997; Bietak 2010a; Bietak 2011; Bietak 2013a; Bietak et al. 2016; Mourad 2015; O’Connor 1997). The Tell el-Dab ${ }^{c}$ a stratigraphy system is compared to relative and estimated absolute chronologies in Fig. 3.

Samples come from cemeteries in three excavated areas (Fig. 4). Area A/I, the smallest and least published of the three areas (Prell and Rahmstorf 2019), yielded only one individual for isotopic analysis. Area A/II is the largest excavated cemetery of the site, the most comprehensively published area of Tell el-Dab ${ }^{\mathrm{c}}$ a and provided the majority of samples for this study. Online Resource 3 is a map of the area, with burials analyzed in this study marked. Occupation of A/II began with small-scale settlement activity during phases H-G/1 (van den Brink 1982). From phase E/2 through $\mathrm{D} / 2$, an eastern Delta material culture, associated with the Fifteenth Dynasty, appeared (ForstnerMüller 2010). Large temples were built in A/II during phases F-E/2, most notably Temple III which experienced continued use throughout the time period (Bietak 2009; Bietak 2016). The continued occupation of this temple, along with unchanging land plots (interpreted as persistence of land ownership), has been suggested as indicative of wider continuation spanning from before the Hyksos period (Bietak 2016; Forstner-Müller 2010).

The earliest occupation in Area F/I dates to the 12th Dynasty, strata e/2-3 (i.e., phase N/2-3; note that Area F/I uses a local stratigraphy system denoted in lower case but relating to the phases of area $\mathrm{A}$ in capitals) (Czerny and von den Driesch 1999). Excavations from stratum d/2 (phase H) unearthed examples of non-local customs, including domestic architecture, pottery, and interments containing Near Eastern style metalwork as grave goods (Philip 2006). A range of burial structures during strata $d /$ 1-2 (phases G/4-H) in Area F/I have tomb architecture unique to the area and stratum. After strata $d / 1-2$, burial structures unify and resemble those of the rest of the site (Schiestl 2008; Schiestl 2009).

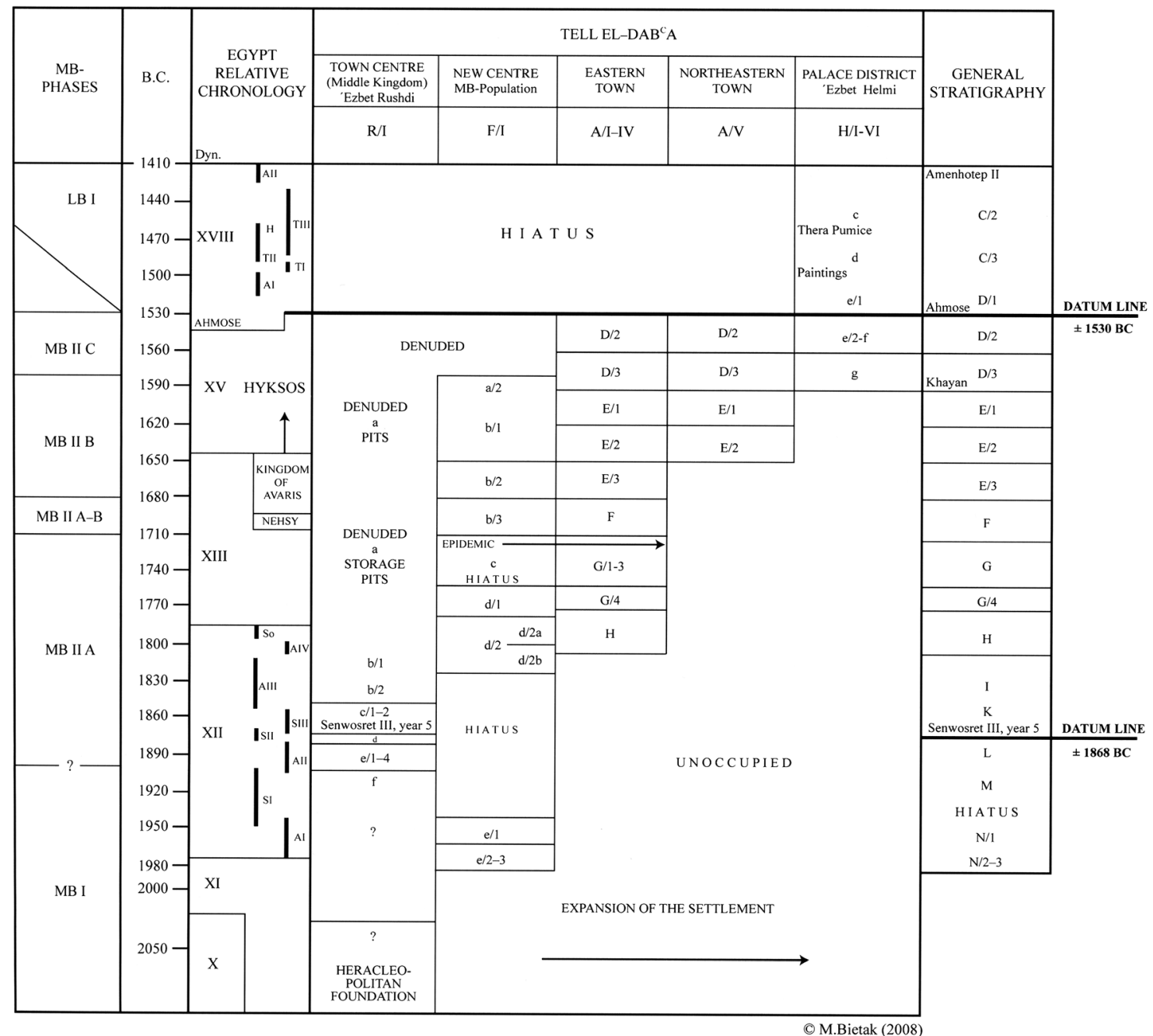

Fig. 3 Site stratigraphy system of Tell el-Dab ${ }^{c} a$ 


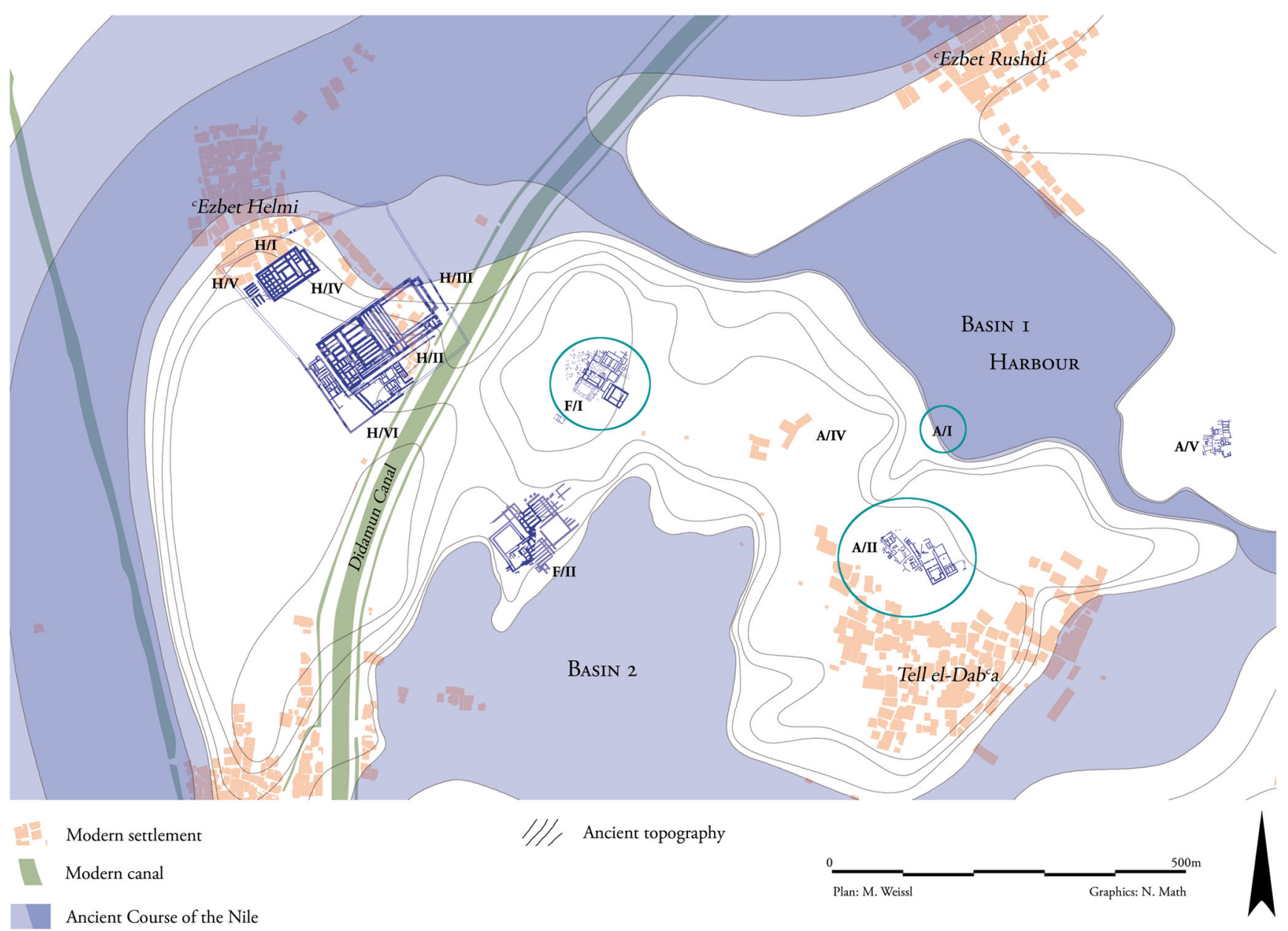

Fig. 4 Site plan of Tell el-Dab ${ }^{\mathrm{c}}$ a along with nearby sites of Ezbet Helmi and Ezbet Rushdi. Cemeteries with analyzed samples circled. Modified from Stantis et al. (2020)

A site chronology has been established by timelines provided by a stela of Sesostris III, the (at least partial) abandonment of the site at the end of the Hyksos Period, comparisons of ceramics with well-dated sites in Egypt and Ashkelon (Bietak 2002; Bietak 2010b). The offsets to the ${ }^{14} \mathrm{C}$ dating (Kutschera et al. 2012) demanded re-evaluation after annual tree-ring measurements (Pearson et al. 2018). In order to address the question of chronological patterns of movement, we collapse the detailed timescale to a simple 'Pre-Hyksos' time period (1991-1649 BCE) and the Hyksos reign. Absolute and relative chronologies of the site are still debated (e.g., Bietak 2013b; Höflmayer 2019), and so, the current study relies on stratigraphy which retains the relative temporal distances between the burials.

\section{The Elite of the Elite?}

Tell el-Dab ${ }^{\mathrm{c}}$ a cemeteries are posited to have generally interred the elites of the city (Philip 1989), although Bader (2020) points out there are some simple pit burials with no or few grave goods within the cemeteries. Several individuals are especially notable in their funerary wealth even among the elite assemblage. These individuals are notable for being buried in at least one of three themes of particularly elite burial custom: equid burials, weapons burials, or buried with servants (Table 1).

Throughout all three cemetery areas, some richly appointed constructed tombs had equids (i.e., donkeys) placed outside the tomb; these equid burials are an elite burial tradition found in the Fertile Crescent since the Early Bronze Age (c. 3000 BCE) (Forstner-Müller 2008; Prell 2019b; Schiestl 2009). Double equid burials (two equids placed outside the tomb, often oriented as though they are ready to pull a cart) are the common configuration for this rare burial form at Tell el$\mathrm{Dab}^{\mathrm{c}} \mathrm{a}$, and three burials with equids interred at the entrance of the tomb were available for isotopic analysis. The burial of $\mathrm{A} / \mathrm{II}-1 / 12$ Tomb 5 is notable for having five equids buried in the entrance pit outside the tomb as well as select burial goods including a narrow-bladed bronze battle-axe and a scarab bearing the name 'Deputy treasurer, Aamu (i.e., Asiatic)' (Bietak 1991; Prell 2019b). A/II-n/13 Tomb 8 (with two individuals excavated from the tomb) is identified as an equid 
Table 1 Elite and servant burials available for isotopic analysis. Burials marked with * are contentious in archaeological interpretation (see Bietak 1989; van den Brink 1982)

\begin{tabular}{|c|c|c|c|c|c|}
\hline Burial number & Phase & Equid burial & Buried with attendant & Weapon burial & Attendant \\
\hline A/II-1/11 Tomb 3, Burial 1* & $\mathrm{F}$ & & $\mathrm{X}$ & & \\
\hline A/II-1/12 Tomb 5, Burial 1 & $\mathrm{~F}$ & $\mathrm{X}$ & $\mathrm{X}$ & $\mathrm{X}$ & \\
\hline A/II-1/16 Tomb 4, Burial 1 & $\mathrm{~F}$ & & & $\mathrm{X}$ & \\
\hline A/II-m/10 Tomb 8, Burial 1 & $\mathrm{~F}$ & & & $X$ & \\
\hline A/II-n/13 Tomb 8, Burial 1* & $\mathrm{D} / 3$ & $\mathrm{X}$ & & & \\
\hline A/II-n/13 Tomb 8, Burial 2* & $\mathrm{D} / 3$ & $X$ & & & \\
\hline $\mathrm{A} / \mathrm{II}-\mathrm{o} / 20$ Tomb 4 & $\mathrm{E} / 1$ & & & $\mathrm{X}$ & \\
\hline A/II-1/12 Tomb 5, Burial 2* & $\mathrm{F}$ & & & & $\mathrm{X}$ \\
\hline A/II-1/12 Tomb 5, Burial 3* & $\mathrm{F}$ & & & & $\mathrm{X}$ \\
\hline A/II-m/16 Tomb 2, Burial 1 & $\mathrm{~F}$ & & & & $\mathrm{X}$ \\
\hline
\end{tabular}

burial by Wapnish (1997), although zooarchaeological records only suggest scattered equid bones outside the tomb (Boessneck and von den Driesch 1992); Wapnish might have interpreted the bones as evidence of a disturbed equid burial and is therefore included in this investigation.

Individuals associated with burial items of copper alloy weaponry (e.g., axes, swords, javelins, and daggers) are another funerary category often associated with socio-economic wealth in the Levant and parts of the northeastern Nile Delta during this time period (Cohen 2012; Philip 1995; Prell 2019a). This bronze weaponry is associated with the idealization of a 'warrior culture' with socially elite males being buried with bronze weaponry that often appears decorative rather than functional.

'Attendant burials' outside of constructed tombs also set some burials apart at Tell el-Dab ${ }^{\mathrm{c}}$ a (Bietak 1989; van den Brink 1982); these are burials located outside the front entrance of constructed tombs, seemingly contemporaneously deposited along with the elite(s) buried in the constructed tomb, with no burial offerings associated with the individuals outside the tomb. Outside the constructed tomb of A/II-1/12 Tomb 5, two humans (designated A/II-1/12 Tomb 5, Burials 2 and 3) were buried in the entrance pit along with the five equids. The tomb of A/II-1/11 Tomb 3 also had burials placed outside the entrance pit and the individual inside the constructed tomb (Burial 1) was available for comparison.

There is some re-interpretation with later analysis of the excavation, suggesting that Burials 2 and 3 mentioned above might be earlier burials disturbed by the equid pit (Bietak 1989). Regarding the attendants outside A/II-1/12 Tomb 5, Burial 2 was estimated osteologically to be a male, while all other attendant burials in Tell el-Dab ${ }^{\mathrm{c}}$ a were estimated as females by initial osteological assessment (Bietak 1989; van den Brink 1982). A/II-1/11 Tomb 3 is also contentious as to whether the burials outside the tomb are attendants as they were endowed with some offerings. In addition, the right foot of A/II-1/11 Tomb 3 Burial 1 was covered by the eastern side wall of the neighboring Tomb 2, suggesting intercutting and different interment times. In favor of the attendant burial interpretation, the two individuals are in the position where one would expect the entrance pit of A/II-1/11 Tomb 3. If these burials were older than this tomb group, they would have been disturbed by the entrance pit.

These seven especially richly appointed burials are worth further qualitative examination as a small subgroup to investigate whether these individuals share patterns in diet or mobility. The two possible 'attendant burials' of A/II-1/12 Tomb 5, Burials 2 and 3 are also available for isotopic analyses, along with an attendant burial outside the tomb of A/II-m/16 Tomb 2, Burial 1.

\section{Previous ${ }^{87} \mathrm{Sr} /{ }^{86} \mathrm{Sr}$ evidence at Tell el-Dabca}

Previous research on Tell el-Dab ${ }^{\mathrm{c}}$ a individuals using ${ }^{87} \mathrm{Sr} /{ }^{86} \mathrm{Sr}$ analysis of tooth enamel highlighted that the site has always been a cosmopolitan hub of movement, with more than half of all individuals (40/75 or 53\%) originating from outside the Nile Delta (Stantis et al. 2020). When comparing time periods, more non-locals were identified during the pre-Hyksos time period, lending support to the supposition that the Hyksos rise to rule was reinforced by immigrants who had moved into the Delta region during the Middle Kingdom and built a socio-economic base of power, rather than the result of an invasion as popularly theorized in apocryphal stories (Dillery 1999; Josephus 1849; Mourad 2015; Redford 1970). Significantly more women moving into the city rather than men might suggest exogamous marriage practices and patrilocality, and further does not support the notion of an invading force as the Hyksos mechanism of taking control (Stantis et al. 2020). 


\section{Materials and methods}

\section{Sample collection}

During excavations at Tell el-Dab ${ }^{c}$ in the late 1960s and early 1970s, archaeological samples were exported to Vienna, Austria. Permission from curation institutions was secured in order to sample, export, and perform destructive analysis on select pieces of human bone and teeth.

Second permanent molars or permanent premolars (first or second) were selected as these teeth, whether mandibular or maxillary, complete crown formation between 5 and 8 years of age of the individual (AlQahtani et al. 2010). Teeth with cavitated carious lesions were avoided to minimize variation from pathological changes to the enamel (Plomp et al. 2020). For dietary isotopes from bone collagen, samples of $\sim 800 \mathrm{mg}$ were taken from cortical bone. Bones with pathological changes were excluded on the principle that disease-related changes in the tissue's metabolic pathways may affect the isotope values (Katzenberg and Lovell 1999).

Age and sex estimations were determined using standard bioarchaeological methods (Brickley and McKinley 2004; Buikstra and Ubelaker 1994), with Winkler and Wilfing's observations as field osteologists at the site used as supplementary information (Winkler and Wilfing 1991).

\section{Sample preparation and analysis}

After burring to remove the outer surface, enamel was removed from the tooth using a dental cutting instrument with a rotary saw attachment. Any dentine attached was gently burred. The enamel was powdered in an agate mortar and pestle and then pretreated with $0.1 \mathrm{M}$ acetic acid at room temperature for no longer than $4 \mathrm{~h}$. The powders were then rinsed $3 \times$ with ultrapure water and then dried in a $50^{\circ}$ oven overnight.

Carbon $\left(\delta^{13} \mathrm{C}\right)$ and oxygen $\left(\delta^{18} \mathrm{O}\right)$ isotope ratios were measured in the carbonate $\left(\mathrm{CO}_{3}\right)$ component of tooth enamel following the procedures of Bentley et al. (2007). For each tooth, approximately $2 \mathrm{mg}$ of powdered sample was reacted with $99 \%$ ortho-phosphoric acid for $2 \mathrm{~h}$ at $70{ }^{\circ} \mathrm{C}$. The resultant gas mix of helium and $\mathrm{CO}_{2}$ was then purified in a Thermo Fisher Scientific Gasbench II then passed directly into a Thermo Fisher Scientific MAT 253 gas source mass spectrometer for isotopic analysis. Both $\delta^{13} \mathrm{C}$ and $\delta^{18} \mathrm{O}$ values are presented in per mill (\%o), $\delta^{13} \mathrm{C}$ is presented relative to VPDB, and $\delta^{18} \mathrm{O}$ is presented relative to VSMOW. Duplicate analysis of samples yielded a precision with a mean difference of $0.37 \%$ (2 SD) for $\delta^{13} \mathrm{C}$ and $0.32 \%$ (2 SD) for $\delta^{18} \mathrm{O}$. International reference carbonate materials NBS $19(n=$ $3)$, IAEA-CO-1 $(n=3)$, and LSVEC $(n=3)$ were analyzed during each run to monitor performance and normalize the isotopic data. Two internal standards: carbonate DCS01 $(n=$
7) and equid tooth enamel Dobbins $(n=2)$ were also analyzed in each run. International standards yielded reproducibility better than $0.20 \%$ ( $2 \mathrm{SD}$ ) for $\delta^{13} \mathrm{C}$ and $0.24 \%$ (2 SD) for $\delta^{18} \mathrm{O}$. All values have been normalized to the accepted values of $+2.49 \%$ VPDB and $-46.6 \%$ VPDB for $\delta^{13} \mathrm{C}$ and $2.40 \%$ VPDB and $-26.70 \%$ VPDB for $\delta^{18} \mathrm{O}$, for IAEACO-1 and LSVEC, respectively. In order to compare $\delta^{18} \mathrm{O}_{\text {carb }}$ values to local water, the carbonate values were converted to drinking water $\left(\delta^{18} \mathrm{O}_{\mathrm{dw}}\right)$ using Daux et al.'s Equation 6 (Daux et al. 2008).

FTIR (Fourier transformation infrared spectroscopy) analysis can be utilized for preservation assessment (Beasley et al. 2014; France et al. 2020; Hollund et al. 2013). Although $\delta^{18} \mathrm{O}$ and $\delta^{13} \mathrm{C}_{\text {carbonate }}$ can have preservation issues, especially surrounding recrystallization of the inorganic matrix, FTIR was not included in this study as spectroscopic indicators are not necessarily reliable for ascertaining the level of diagenetic changes (Trueman et al. 2008). Bone can be used in studies where diagenetic effects are not thought to have affected ${ }^{87} \mathrm{Sr} /{ }^{86} \mathrm{Sr}$ and $\delta^{18} \mathrm{O}$ values, but tooth enamel is more resistant to leaching and contamination from the burial environment (Hoppe et al. 2003; Trickett et al. 2003). For bone and dentine, collagen extraction and purification were carried out using a modified Longin method using $0.3 \mathrm{M} \mathrm{HCl}$ for 'gentler' demineralization (Brown et al. 1988; Longin 1971). Given a potentially poor preservation at the site, a pilot group was selected for demineralization (Online Resource 1). All samples from the pilot study to test collagen preservation in this assemblage either had no collagen 'survive' the demineralization process (i.e., complete dissolution in the $0.3 \mathrm{M} \mathrm{HCl}$ solution) and so no collagen could be analyzed in the mass spectrometer, or the samples that did yield enough product to analyze exhibited collagen quality indicators $(\% \mathrm{C}, \% \mathrm{~N}$, $\mathrm{C} / \mathrm{N})$ suggestive of poor preservation and/or contamination (Ambrose and Norr 1993). As such, the $\delta^{13} \mathrm{C}$ and $\delta^{15} \mathrm{~N}$ from collagen are not discussed further in the results and discussion of this paper.

\section{Statistical analysis}

$\mathrm{R}$ was used for statistical analysis and graph generation ( $\mathrm{R}$ Core Team 2000). Shapiro-Wilk tests were used to test the null hypothesis that $\delta^{18} \mathrm{O}$ and $\delta^{13} \mathrm{C}$ data were normally distributed. If normally distributed, Welch two-sample $t$ tests were used to assess for significant differences in variance; if not normally distributed, Kruskal-Wallis tests were used. With non-locals identified using previously published ${ }^{87} \mathrm{Sr} /{ }^{86} \mathrm{Sr}$ along with this study's $\delta^{18} \mathrm{O}$ values, we can also assess the relationship between locality and the sexes as well as compare time periods using chi-squared tests. A generalized logistic regression model using both sex and time period as independent variables would be ideal, but the sample size is too small when both variables are included. 
Table 2 Summary values of $\delta^{13} \mathrm{C}$ and $\delta^{18} \mathrm{O}$ values from enamel

\begin{tabular}{|c|c|c|c|c|c|c|c|c|c|c|c|}
\hline & \multicolumn{2}{|c|}{$\delta^{13} \mathrm{C}_{\mathrm{carb}}(\mathrm{VPBD})$} & \multirow[b]{2}{*}{ Min } & \multirow[b]{2}{*}{ Max } & \multirow[b]{2}{*}{ Median } & \multicolumn{2}{|c|}{$\delta^{18} \mathrm{O}_{\text {carb }}(\mathrm{VSMOW})$} & \multirow[b]{2}{*}{ Min } & \multirow[b]{2}{*}{ Max } & \multirow[b]{2}{*}{ Median } & \multirow[b]{2}{*}{$n$} \\
\hline & Mean & SD & & & & Mean & SD & & & & \\
\hline Total & -11.4 & 0.7 & -13.5 & $-9.6-11.4$ & -11.4 & 28.5 & 1.5 & 25.3 & 31.8 & 29.1 & 75 \\
\hline \multicolumn{12}{|l|}{ Sex } \\
\hline Female & -11.4 & 0.6 & -12.8 & 9.6 & -11.44 & 28.0 & 1.5 & 25.3 & 30.8 & 28.5 & 30 \\
\hline Male & -11.5 & 0.8 & 13.5 & -10.6 & -11.4 & 28.6 & 1.5 & 25.8 & 31.0 & 29.2 & 20 \\
\hline \multicolumn{12}{|l|}{ Time period } \\
\hline Pre-Hyksos & -11.6 & 0.6 & -13.5 & -10.3 & -11.6 & 28.2 & 1.7 & 25.3 & 31.4 & 28.6 & 37 \\
\hline Hyksos & -11.2 & 0.5 & -12.2 & -9.6 & -11.1 & 28.5 & 1.5 & 25.5 & 31.2 & 29.1 & 30 \\
\hline \multicolumn{12}{|l|}{ Area } \\
\hline $\mathrm{A} / \mathrm{I}$ & -11.2 & --- & & & & 29.4 & --- & & & & 1 \\
\hline $\mathrm{A} / \mathrm{II}$ & -11.4 & 0.7 & -13.5 & -9.6 & 11.4 & 28.6 & 1.5 & 25.6 & 31.4 & 29.2 & 66 \\
\hline $\mathrm{F} / \mathrm{I}$ & -11.6 & 0.8 & -12.9 & -10.6 & -11.5 & 27.6 & 2.1 & 25.3 & 31.8 & 26.9 & 8 \\
\hline
\end{tabular}

\section{Results}

Of the 75 individuals, $\delta^{18} \mathrm{O}_{\text {carb }}$ values (VSMOW) range from 25.3 to 31.8 (mean $28.5 \pm 1.5 \mathrm{SD}$ ). $\delta^{13} \mathrm{C}_{\text {carb }}$ values range from -13.5 to -9.6 (mean $-11.4 \pm 0.7 \mathrm{SD}$ ). A summary of the $\delta^{13} \mathrm{C}$ and $\delta^{18} \mathrm{O}$ data is shown in Table 2, with the full dataset available as Online Resource 2 and ready for import into $\mathrm{R}$ for use with this study's code as Online Resource $4 . \delta^{13} \mathrm{C}_{\text {carb }}$ data are normally distributed (Shapiro-Wilk $=0.986, p=0.575$ ) but the $\delta^{18} \mathrm{O}$ data are not (Shapiro-Wilk $=0.942, p=0.002$ ).

The individuals sampled were excavated from three areas of the site: A/I $(n=1), \mathrm{A} / \mathrm{II}(n=66)$, and $\mathrm{F} / \mathrm{I}(n=8)$. Comparing between excavated areas, $\mathrm{F} / \mathrm{I}$ and $\mathrm{A} / \mathrm{II}$ show no significant differences in $\delta^{18} \mathrm{O}$ values $(W=368, p=0.072)$ and no significant differences in $\delta^{13} \mathrm{C}_{\text {carb }}$ values $(t(73)=$ $0.455, p=0.6611)$. With the great disparity in sample sizes, we acknowledge that there might be great differences between the areas, but A/II is going to dominate the patterns between sexes and simplified time phases. Without access to more individuals from $\mathrm{A} / \mathrm{I}$ and $\mathrm{F} / \mathrm{I}$, there is no current means of investigating these site areas without combining them with A/II for investigating site-wide patterns between sexes and simplified time phases. Within Area A/II, there is no discernible spatial patterning of differential interment arrangements between locals and non-locals (Online Resource 3).

There are no differences between the sexes in $\delta^{13} \mathrm{C}_{\text {carb }}$ values $(t(49)=0.675, p=0.504)$ or $\delta^{18} \mathrm{O}_{\text {carb }}$ values $(W=$ $220.5, p=0.118)$. There are significant differences in $\delta^{13} \mathrm{C}$ carb values between the time periods $(t(66)=-3.66, p<0.001)$ but no significant difference regarding $\delta^{18} \mathrm{O}_{\text {carb }}$ values $(W=$ 495, $p=0.453$ ).

The oxygen stable isotope results, when converted to $\delta^{18} \mathrm{O}_{\mathrm{dw}}$ (VSMOW), show a wide range of values, -8.4 to + $1.9 \%$. The median, $-2.4 \%$, is close to the estimated value of Nile water pre-damming $(-2.8 \% o)$. There is a distinct cluster of individuals around that median, circled in Fig. 5, although a bimodal distribution is also observed when the data is plotted as a histogram. The enamel carbonate values, when converted to drinking water, largely do not overlap with the modern precipitation values of $-0.4 \pm 1.3 \%$ estimated using the tool by Bowen (2018) nor the modern ground and well water samples collected by various environmental researchers which showed an average value of $2.23 \pm 1.43 \%$. With these modern averages not aligning with the archaeological human values, the cluster of individuals around the median is used as the 'local' $\delta^{18} \mathrm{O}$ values instead.

We then use the median $\delta^{18} \mathrm{O}$ cluster along with the previously published strontium data to re-assess the 'local' values by designating any individual outside both local ${ }^{87} \mathrm{Sr} /{ }^{86} \mathrm{Sr}$ values and the median $\delta^{18} \mathrm{O}$ cluster as a non-local (Fig. 6). With both isotopic values utilized, five more individuals are deemed non-local than if only ${ }^{87} \mathrm{Sr} /{ }^{86} \mathrm{Sr}$ is used, four individuals with higher oxygen stable isotope values than the median cluster and one lower. A group of individuals separates from the rest of those sampled with low $\delta^{18} \mathrm{O}$ values and high ${ }^{87} \mathrm{Sr} /{ }^{86} \mathrm{Sr}$ values, in of lower-right corner of Fig. 6. Tabulating the number of locals and non-locals by time period, sex, and site area help visualize the relative proportions between groups (Table 3 ).

With locals and non-locals determined using $\delta^{18} \mathrm{O}$ and ${ }^{87} \mathrm{Sr} /{ }^{86} \mathrm{Sr}$ combined, we can compare these two groups' diet in terms of $\delta^{13} \mathrm{C}_{\text {carb }}$ values (Fig. 7). Non-locals show a wider range of $\delta^{13} \mathrm{C}_{\text {carb }}$ values $(-13.5$ to $-9.6 \%$ ) than locals $(-12.1$ to $-10.3 \%$ ). However, there are no statistically significant differences in the mean values between locals and non-locals (again, using ${ }^{87} \mathrm{Sr} /{ }^{86} \mathrm{Sr}$ and $\delta^{18} \mathrm{O}$ combined) regarding $\delta^{13} \mathrm{C}_{\text {carb }}$ values, $t(74)=1.883, p=0.064$. There is a weak but significant correlation between $\delta^{13} \mathrm{C}_{\text {carb }}$ and ${ }^{87} \mathrm{Sr} /{ }^{86} \mathrm{Sr}$ values, $t(73)=$ $-3.04, p=0.003$. When plotting locals and non-locals with separate linear regression lines, locals once again show little 


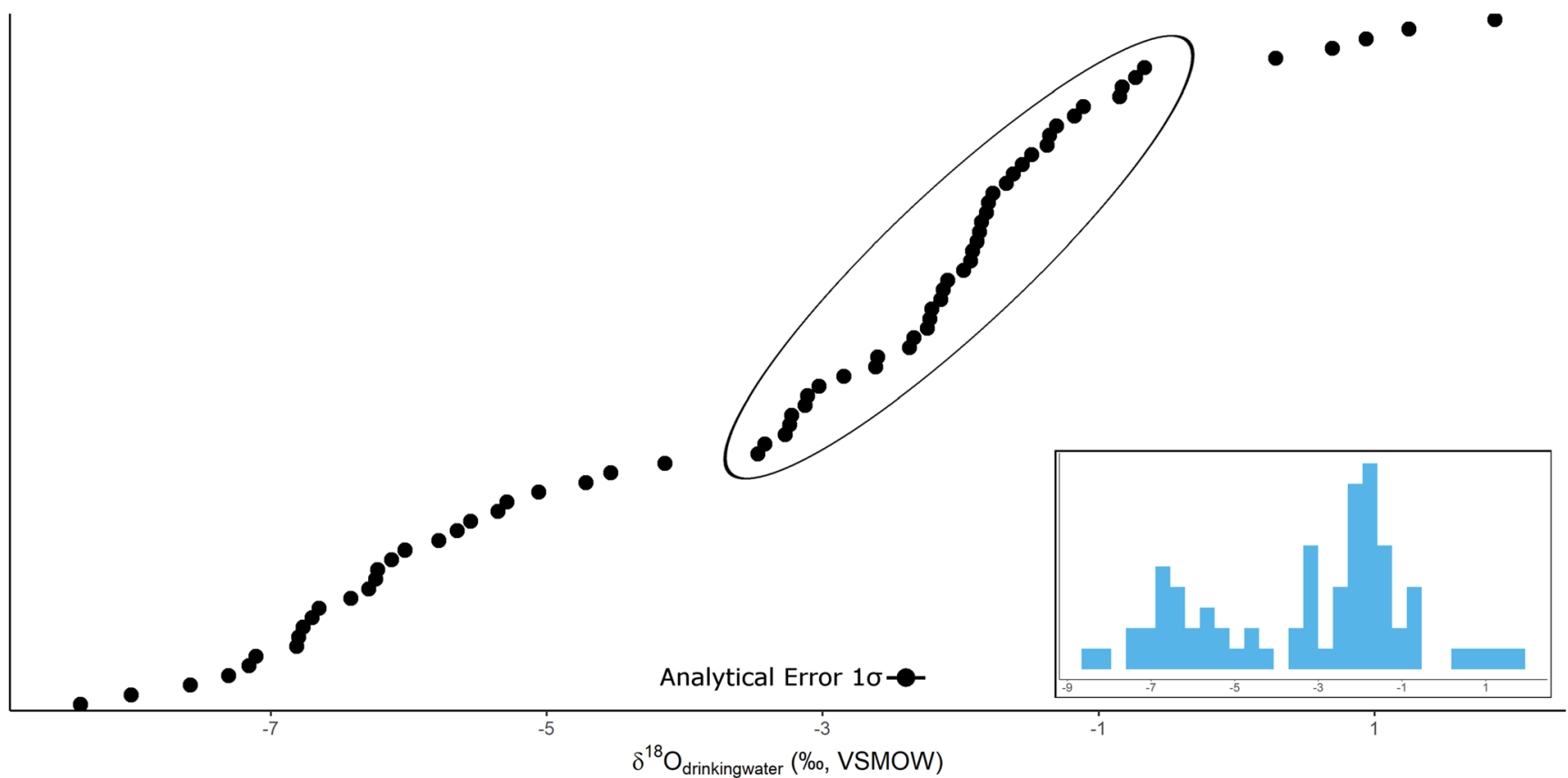

Fig. $5 \delta^{18} \mathrm{O}_{\mathrm{dw}}$ values of all individuals from the archaeological site of Tell el-Dab ${ }^{\mathrm{c}} \mathrm{a}$, with histogram inset. Cluster near median circled

variation in $\delta^{13} \mathrm{C}_{\text {carb }}$ values, but non-locals display a negative relationship between $\delta^{13} \mathrm{C}_{\text {carb }}$ and ${ }^{87} \mathrm{Sr} /{ }^{86} \mathrm{Sr}$ values (Fig. 8).

Although there were a greater proportion of female nonlocals $(24 / 30$ or $80 \%)$ compared to male non-locals (10/20 or $50 \%$ ), the proportion of non-locals did not differ significantly by sex, $\chi^{2}(1, n=50)=3.68, p=0.055$. There was a significantly greater proportion of non-locals during the pre-Hyksos occupation of Tell el-Dab ${ }^{\mathrm{c}}$ a $(27 / 35$ or $77 \%)$ compared to the Hyksos time period $(14 / 32$ or $44 \%), \chi^{2}(1, n=67)=6.51, p=$ 0.011 .

Those individuals buried in especially elite funerary traditions (and three of the attendant burials) are highlighted on Fig. 9. Four of the seven elite burials show local isotopic values. One individual (A/II-m/10 Tomb 8, Burial 1) displays ${ }^{87} \mathrm{Sr} /{ }^{86} \mathrm{Sr}$ ratio just outside the biospheric range $(0.7078025$ compared to the established local ${ }^{87} \mathrm{Sr} /{ }^{86} \mathrm{Sr}$ range of 0.7076128-0.7078005). Another (A/II-1/12 Tomb 5, Burial 1) displays a local ${ }^{87} \mathrm{Sr} /{ }^{86} \mathrm{Sr}$ ratio but higher $\delta^{18} \mathrm{O}$ values outside the median cluster. One of the three attendants appears to be local. All elite and servant burials display $\delta^{13} \mathrm{C}$ values within the assemblage's median $\pm 1.5 \mathrm{IQR}$.

\section{Discussion}

Using the group median to assign locality is not an ideal method, but the modern environmental water values were well outside the values measured in this assemblage. The modern precipitation values calculated using Bowen (2018) might not be reflective of contemporaneous precipitation due to climate shifts over time, and a larger settlement such as Tell el-Dab ${ }^{c} a$ could not have relied year-round on rainwater given the arid climate. Modern ground and well water sampled in the region display values much more positive than most enamel carbonate samples analyzed in this study. Given that the settlement was on the Pelusiac Branch, Nile water might have been utilized more than well water at Tell el-Dab ${ }^{c}$. The alignment of the assemblage median $\delta^{18} \mathrm{O}_{\mathrm{dw}}$ value of $-2.4 \%$ o to the estimated pre-damming Nile River value of $-2.8 \%$ o lends some strength to this idea.

Regarding Question One of this research (whether the oxygen stable isotope data agreed with the strontium data for who is non-local), the oxygen and strontium isotopic data are not in perfect agreement with identifying non-locals. If used alone, $\delta^{18} \mathrm{O}$ clustering near the median would not be sufficient patterning for identifying locality. When strontium

Table 3 Cross tabulation of locality by time period, sex, and site area

\begin{tabular}{lll}
\hline & Local & Non-local \\
\hline Total & 30 & 45 \\
Time period & & \\
Pre-Hyksos & 8 & 26 \\
Hyksos & 18 & 14 \\
Sex & & \\
Female & 6 & 24 \\
Male & 10 & 10 \\
Site area & & \\
A/I & 1 & 0 \\
A/II & 29 & 37 \\
F/I & 0 & 8 \\
\hline
\end{tabular}




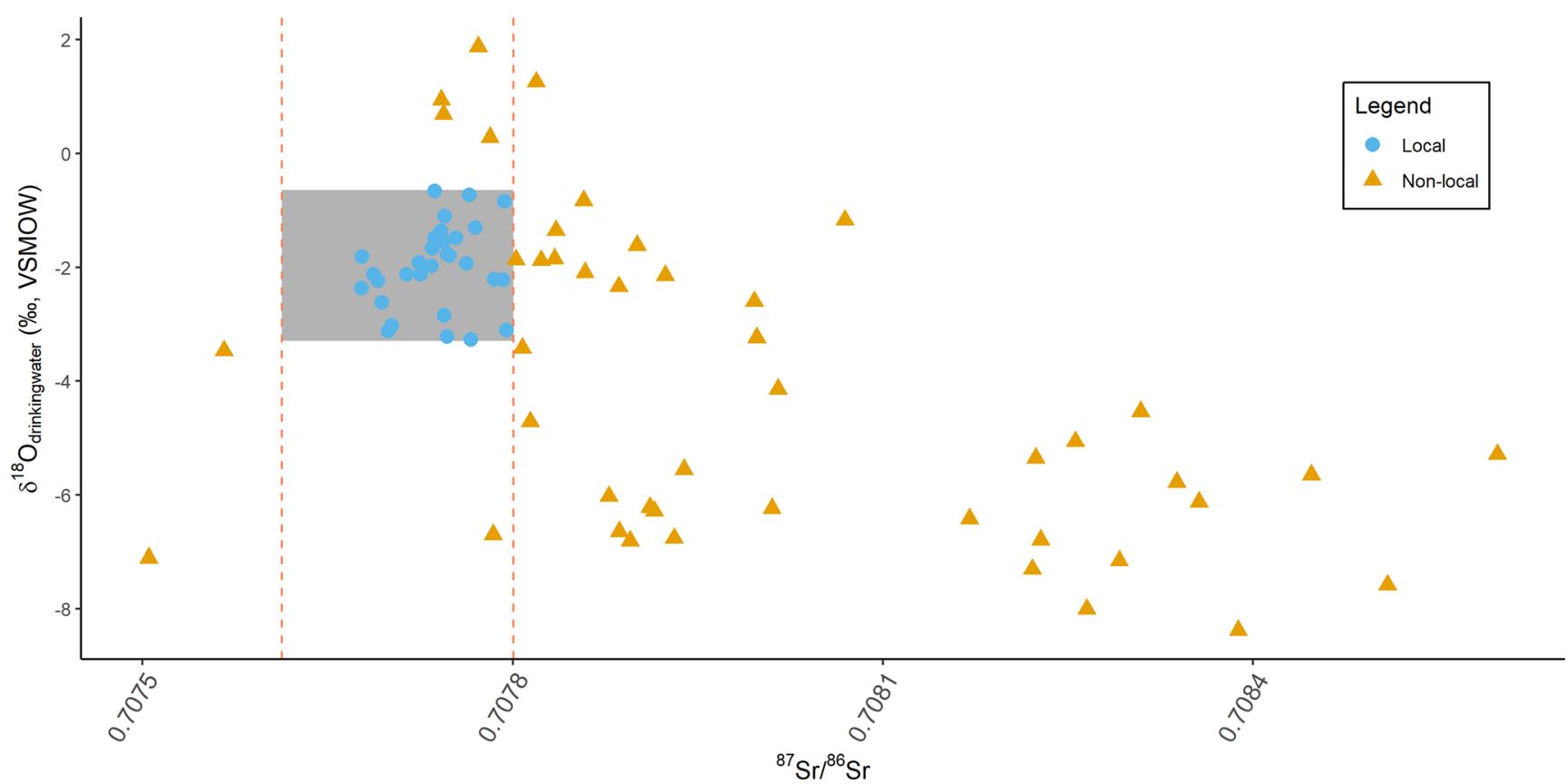

Fig. $6 \delta^{18} \mathrm{O}_{\mathrm{dw}}$ and ${ }^{87} \mathrm{Sr} /{ }^{86} \mathrm{Sr}$ values of all individuals. Shaded box represents local biospheric strontium values and median $\delta^{18} \mathrm{O}$ cluster, highlighting 'local' isotopic values

and oxygen isotopes are used in tandem, five individuals previously deemed local using ${ }^{87} \mathrm{Sr} /{ }^{86} \mathrm{Sr}$ biospheric values alone lie outside the local $\delta^{18} \mathrm{O}$ range. Four of these individuals (A/II-1/12 Tomb 4, A/II-1/12 Tomb 5, Burial 1, A/II-m/17 Tomb 3, Burial 10, and A/II-m/15 Tomb 9, Burial 2) display higher $\delta^{18} \mathrm{O}$ values than the local cluster $\left(\delta^{18} \mathrm{O}_{\mathrm{dw}}\right.$ values between 0.3 and $1.9 \%$ ), and one displays lower $\delta^{18} \mathrm{O}$ values than the 'local' values, A/II-n/13 Tomb 1 Burial 4 with a value of $-6.7 \%$.

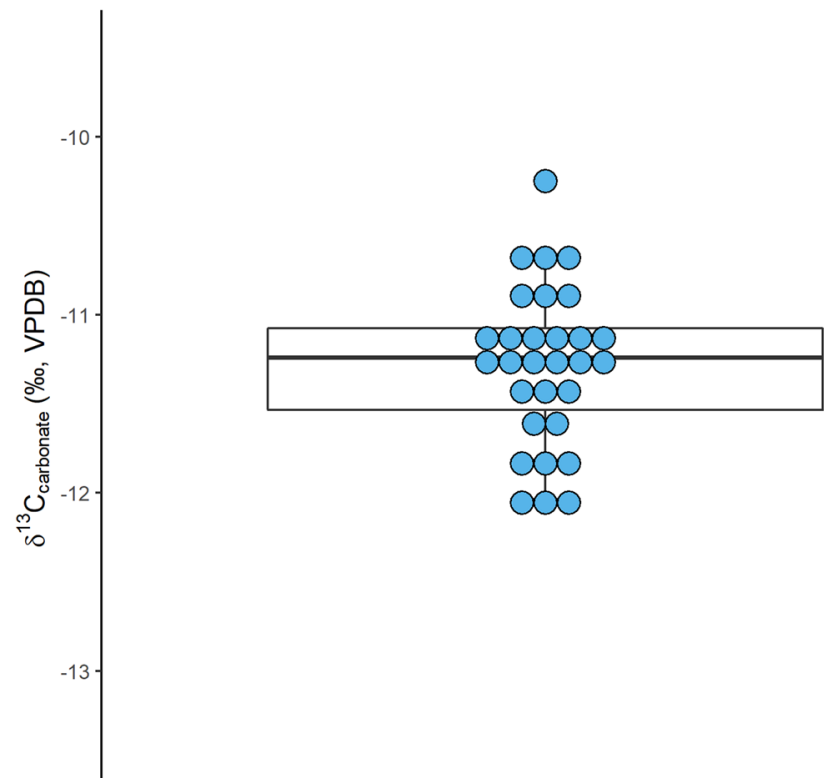

Those four individuals with higher $\delta^{18} \mathrm{O}$ values and local ${ }^{87} \mathrm{Sr} /{ }^{86} \mathrm{Sr}$ values might be non-locals from geographic areas with similar biospheric ${ }^{87} \mathrm{Sr} /{ }^{86} \mathrm{Sr}$ values but a warmer climate, such as the southern regions down the Nile Valley (i.e., Upper Egypt and the Sudan). An alternative interpretation of the data is that these are locals who followed drastically different cultural habits surrounding food and drink. These four might have consumed foods and drink that had been brewed, stewed, or otherwise altered would lead them to reflect higher $\delta^{18} \mathrm{O}$

Local

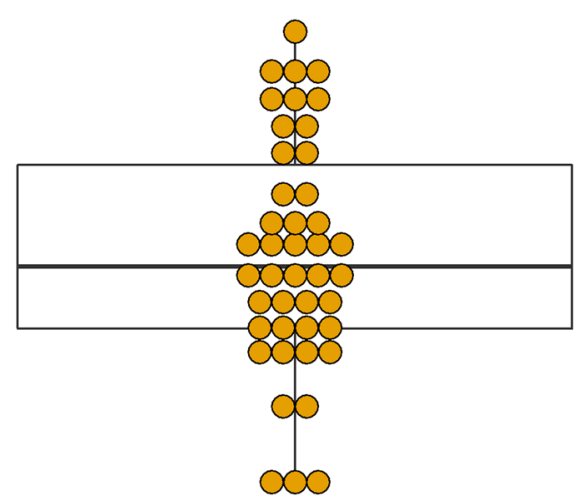

Fig. 7 Box plot comparing local and non-local $\delta^{13} \mathrm{C}_{\text {carb }}$ values 


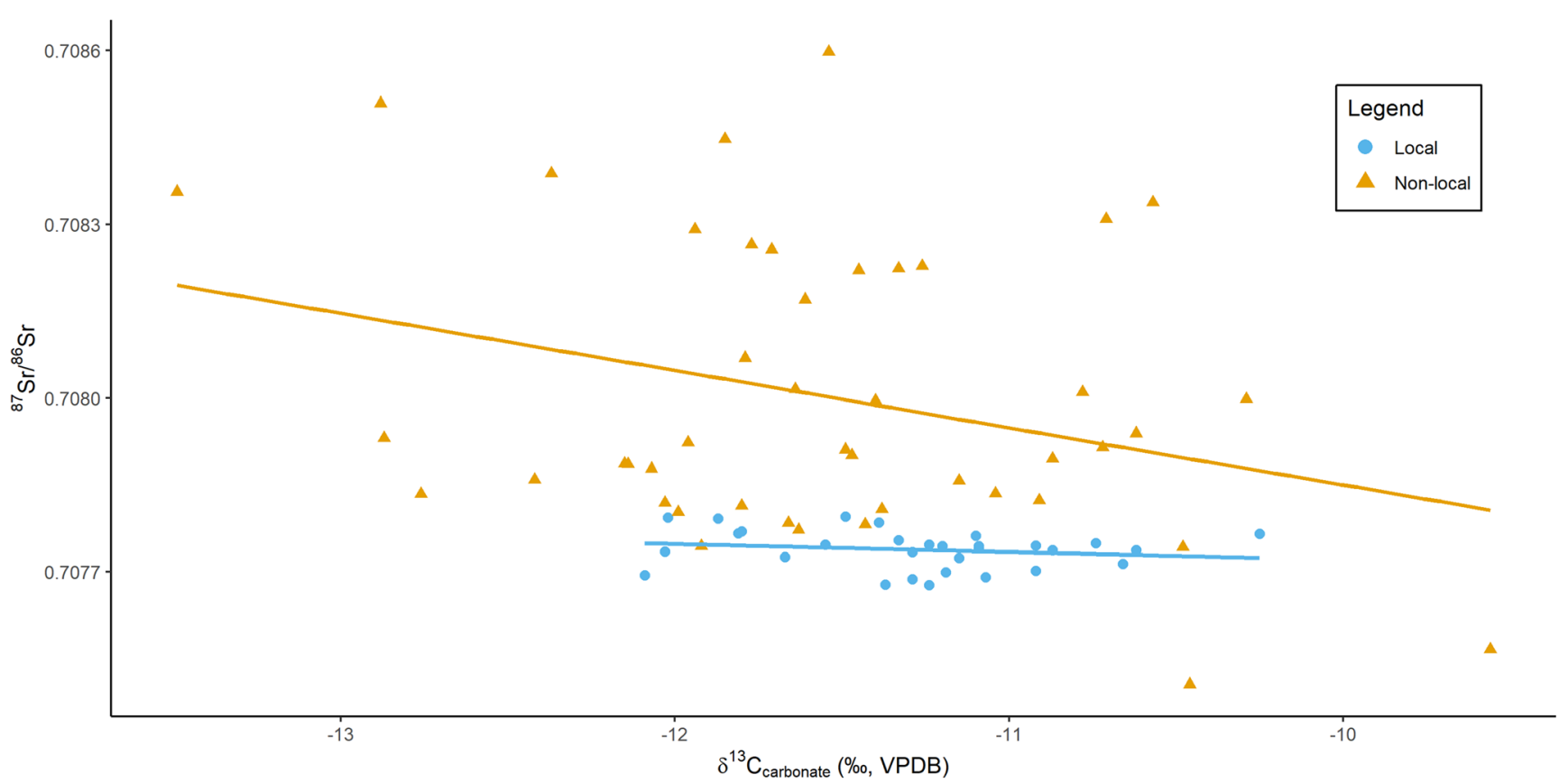

Fig. $8{ }^{87} \mathrm{Sr} /{ }^{86} \mathrm{Sr}$ and $\delta^{13} \mathrm{C}_{\text {carbonate }}$ valued plotted for local and non-locals. Fitted regression line for locals is $y=-1.375 \mathrm{e}-05 \mathrm{x}+0.7076(p=0.131)$; fitted regression line for non-locals is $y=-9.887 \mathrm{e}-05 \mathrm{x}+0.7069(p=0.046)$.

values in their tissues than the rest of the local population (Brettell et al. 2012).

Question Two of this research centered on patterns in migration regarding burial location, the sexes, and time periods. Chi-square tests show non-significant differences in the proportion of non-locals between males and females, but $80 \%$ of females being non-locals deserves contemplation. All analyzed individuals from area F/I are deemed non-locals using combined isotopic values. Like many of the excavation areas, area $\mathrm{F} / \mathrm{I}$ resides on its own separate tell and exhibits unique burial customs during $\mathrm{d} / 1-\mathrm{d} / 2$. However, with only seven individuals total from the area available for analysis during this research project, we are wary of assigning any cultural significance to this pattern.

The aim of investigating Question Three was to explore dietary differences between those born locally and immigrants

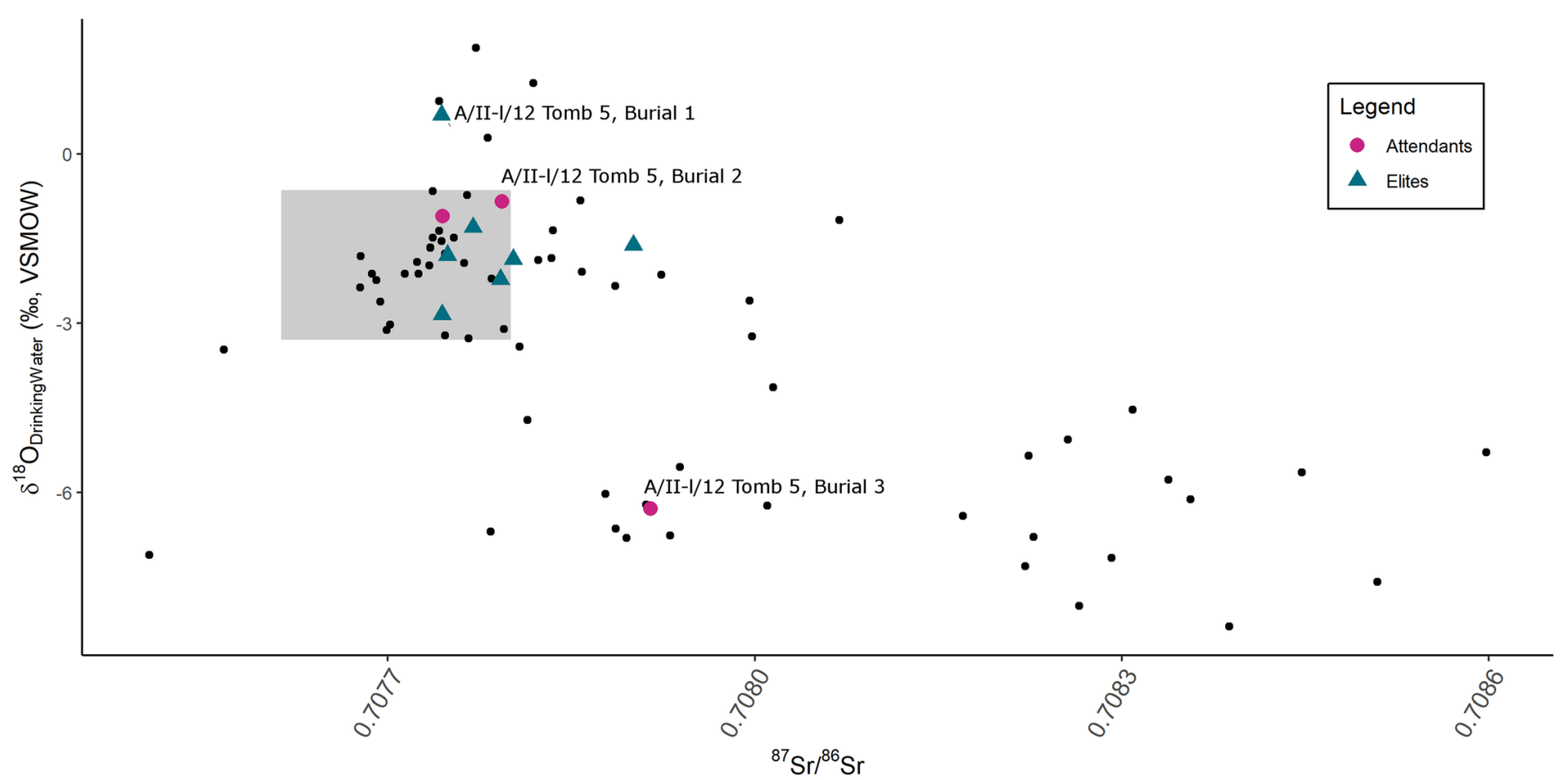

Fig. $9 \delta^{18} \mathrm{O}$ and ${ }^{87} \mathrm{Sr} /{ }^{86} \mathrm{Sr}$ values, with elite and attendant burials highlighted. A/II-1/12 Tomb 5, where the elite and possible attendants were analyzed isotopically, are annotated 
to the area, to assess whether first-generation immigrants were maintaining their culture-specific dietary habits or undergoing dietary acculturation (at least as was observable using stable isotopes analysis). Modern studies of immigrants show that dietary acculturation is multidynamic and complex, with issues such as 'traditional' food availability, desire to acculturate, and religious beliefs having effects on diet and nutrition which in turn have considerable effects on migrant health (Satia-Abouta et al. 2002; Satia 2010; Spallek et al. 2011). In regard to investigating diet and migration using stable isotope analysis, $\delta^{13} \mathrm{C}$ and $\delta^{15} \mathrm{~N}$ values, although traditionally considered 'dietary' isotopes, have been utilized as evidence for immigration in other archaeological contexts (Cheung et al. 2017; Stantis et al. 2016). With no collagen preservation in any bone or dentine samples tested, most dietary inquiries had to be abandoned within this research.

The expression of cultural heritage through cuisine was greatly limited with only $\delta^{13} \mathrm{C}_{\text {carb }}$ values to compare. Though there was a wider range of stable isotope values in non-locals, there were no significant differences in the mean values of the two groups. With $\delta^{13} \mathrm{C}_{\text {carb }}$ values obtained from the same enamel sample used for strontium and oxygen stable isotope analysis, these dietary values are representative of the same time period of tooth formation as when the individual showed non-local values; i.e., these $\delta^{13} \mathrm{C}$ values are representative of the foods consumed when these individuals lived outside the northeastern Nile Delta. That the $\delta^{13} \mathrm{C}$ values show non-local individuals as a heterogeneous group reflects the varied origins of the non-locals in the Tell el-Dab ${ }^{c}$ a assemblage. The similar mean values between the locals and nonlocals echoes the similar isotopic profile of diet in Bronze Age Egypt and the Near East of a major reliance on $\mathrm{C}_{3}$-photosynthetic crops and fodder for animals, with some small proportion of wild $\mathrm{C}_{4}$ plants for subsistence and fodder as well as limited marine input. There were significant differences between time periods in $\delta^{13} \mathrm{C}_{\text {carb }}$ values, but that statistical significance may have little interpretive value, given that the mean values for the pre-Hyksos and Hyksos time periods are -11.6 and $-11.2 \%$, respectively.

With ${ }^{87} \mathrm{Sr} /{ }^{86} \mathrm{Sr}$ ratios ranging from 0.70751 to 0.70860 , those individuals with the higher ${ }^{87} \mathrm{Sr} /{ }^{86} \mathrm{Sr}$ ratios in the assemblage might originate from the coast of the Mediterranean Sea, which has a Holocene composition around 0.7092 (Schildgen et al. 2014). If a positive correlation between $\delta^{13} \mathrm{C}_{\text {carb }}$ and ${ }^{87} \mathrm{Sr} /{ }^{86} \mathrm{Sr}$ were present, coastal life and marine consumption could have been hypothesized. With a negative correlation between these values, another explanation is needed. The negative correlation between $\delta^{13} \mathrm{C}_{\text {carb }}$ and ${ }^{87} \mathrm{Sr} /{ }^{86} \mathrm{Sr}$ values might be because non-locals from homelands with lower ${ }^{87} \mathrm{Sr} /{ }^{86} \mathrm{Sr}$ values might have incorporated more $\mathrm{C}_{4}$ plants such as wild sorghum (Sorghum bicolor) and pearl millet (Pennisetum glaucum) into their diet. Wild sorghum has been found in about $40 \%$ of Neolithic and Bronze Age sites in Nubia
(Fuller 2014), and so this slight change in $\delta^{13} \mathrm{C}$ values might be associated with people originating from the south. There is wide variability in biogenically available strontium due to the heterogenous and complex geological formations along the Nile Valley (Said 2017). Although the Nile River creates somewhat homogenous values as the main source of drinking water and alluvial deposits, individuals outside the catchment might show variable ${ }^{87} \mathrm{Sr} /{ }^{86} \mathrm{Sr}$ ratios and rely on a diet varying from the local Tell el-Dab ${ }^{\mathrm{c}}$ a cuisine. With issues of equifinality and a lack of a biospheric map, it is difficult to confidently postulate a cause for this pattern between $\delta^{13} \mathrm{C}$ and ${ }^{87} \mathrm{Sr} /{ }^{86} \mathrm{Sr}$ values.

Isotopic investigation of mobility identifies first-generation immigrants into the northeastern Nile Delta at Tell el-Dab ${ }^{c}$, but funerary customs instead give insight into those people who, whether recent immigrants or not, identify with these cultural groupings. One of the most finely appointed burials at the site, A/II-1/12 Tomb 5, Burial 1, with his five equids and two potential attendants buried outside the constructed tomb filled with imported and locally sources goods, is among the individuals with $\delta^{18} \mathrm{O}$ values higher than the local values. A diet consisting mostly of exported food and drink could be theorized for the local strontium values and non-local oxygen values; a similar pattern was observed in the remains of the English ruler King Richard III and the consumption of imported wine was hypothesized as the cause (Lamb et al. 2014). Wine and olive oil were highly prized imports from the Levant at this time period (Marcus 1998; Marcus 2007). However, as a sample of enamel from his second molar was selected, large consumption of imported wine and oil during early childhood seem unlikely. The other two equid burials analyzed in this study (A/II-n/13 Tomb 8, Burials 1 and 2) appear to have spent their childhood in the Nile Delta, but were buried in a custom that has ties with the Fertile Crescent and Levantine cultures (Prell 2019b). One of the dislocated individuals (potential attendants) found on top of the equid burials at the entrance pit of A/II-1/12 Tomb 5 displays isotopic values suggestive of being local, while one appears to have spent his childhood elsewhere. The majority of the 'elite of the elite' burials analyzed here show evidence of being born and raised in the northeastern Nile Delta. Four out of seven display local isotopic values, five if A/II-1/12 Tomb 5 Burial 1 is viewed as a local consuming imported goods.

Burial style and grave goods are a longstanding method of identifying migrants through evidenced practice of cultural transmission (Laneri 2007), and the isotopic results in this study suggest that even individuals born and raised in the northeastern Nile Delta continued Levantine burial customs. When initially settling down in the Eastern Delta, those migrants adopted some Egyptian features, such as tomb architecture, wooden coffins, and Egyptian pottery, in their burial assemblages. Nevertheless, they never denied their heritage as 
is shown by the inclusion of Levantine weapons or equid burials in front of the tombs (Prell 2019a; Prell 2019b), before more or less exclusively returning to their traditional customs in the pre- and Hyksos period.

Regarding the final question of this paper, there appear to be no trends in isotopic values associated with those buried in the most elite burial customs nor those buried as attendants. However, it must be noted that the sample size addressing this specific question is small and so interpretive value is somewhat limited. Patterns in terms of common origins do not emerge with isotopic analysis; instead, sociocultural contexts and ideals appear to have been more influential in the shared burial customs in these elite tombs and their attendants. Indeed, a mix of locals and non-locals (presumably those born in the Levant or perhaps even further northeast) following elite funerary customs demonstrates some cultural continuity in this form of signifying identity and displaying socioeconomic power.

\section{Conclusion}

Human dental enamel, dentine, and cortical bone were analyzed for $\delta^{13} \mathrm{C}$ (collagen and carbonate), $\delta^{18} \mathrm{O}$, and $\delta^{15} \mathrm{~N}$. Collagen from bone and dentine did not survive the burial environment for stable isotope analysis, but $\delta^{18} \mathrm{O}$ and $\delta^{13} \mathrm{C}$ from carbonate provided some evidence of diet and mobility in the northeastern Nile Delta. In conjunction with previously published ${ }^{87} \mathrm{Sr} /{ }^{86} \mathrm{Sr}$ data, we found the majority of the assemblage to be non-locals, with a greater proportion of women and pre-Hyksos period individuals compared to males and Hyksos period individuals, respectively. Should any researchers find themselves with the opportunity to isotopically analyze other Tell el-Dab ${ }^{c}$ a individuals, we do not recommend the destruction of bone or dentine collagen for stable isotope analysis.

A limited range of $\delta^{13} \mathrm{C}$ values suggest a diet reliant on $\mathrm{C}_{3}$ crops, in line with the expected Egyptian diet. Non-locals showed wider range of $\delta^{13} \mathrm{C}$ values both above and below the 'local' range, suggesting variance in food acquisition and preparation by some non-locals, but largely no difference in diet were discernible between locals and non-locals. If the non-locals originated from the Levant, a similar diet reliant on $\mathrm{C}_{3}$ crops would be expected and so the lack of variance observable using $\delta^{13} \mathrm{C}$ values is not unexpected. Further avenues of dietary analysis (e.g., dental pathology as evidence of diet) to compare Bronze Age Levantine and Egyptian diets may help define and differentiate the two groups archaeologically.

Focusing on the isotopic profiles of noted individuals within the assemblage, we see both locals and non-locals being buried in elite Asiatic style. This is suggestive of burial customs continuing as practice in Egyptian-born Asiatics.
Supplementary Information The online version contains supplementary material available at https://doi.org/10.1007/s12520-021-01344-x.

Acknowledgements This project was funded by the European Research Council (ERC) under the European Union's Horizon 2020 research and innovation program (grant agreement No 668640). Thanks to Joanne Peterkin of Durham University for her laboratory experience and aid. Thanks to Dr Fabian Kanz of Medical University of Vienna, Katarina Matiasek and Prof Harald Wilfing of the Anthropology Department of the University of Vienna, and Dr Sabine Eggers of the Natural History Museum of Vienna for coordinating the sample permissions. The first author would like to thank Dr Sarah Elliott who never complained when her agate mortar and pestle were 'borrowed' in the lab and promises it always was returned cleaned.

Code availability $\mathrm{R}$ scripts for statistical analyses are provided in the Supplementary Material.

Author contribution C Stantis: Conceptualization, data curation, formal analysis, investigation, methodology, writing-original draft, writingreview \& editing

A Kharobi: Investigation, formal analysis, writing-review and editing

$\mathrm{N}$ Maaranen: Investigation, formal analysis, writing-review and editing

C Macpherson: Formal analysis, providing lab equipment and materials, writing review \& editing

M Bietak: Conceptualization, funding acquisition, writing-review \& editing return S Prell's: Investigation, formal analysis, writing-review \& editing

H Schutkowski: Conceptualization, formal analysis, investigation, methodology, funding acquisition

Funding This project was funded by the European Research Council (ERC) under the European Union's Horizon 2020 research and innovation program (grant agreement No 668640).

Data Availability All relevant data is included in the article or Supplementary Material.

\section{Declarations}

Competing interests The authors declare no competing interests.

Open Access This article is licensed under a Creative Commons Attribution 4.0 International License, which permits use, sharing, adaptation, distribution and reproduction in any medium or format, as long as you give appropriate credit to the original author(s) and the source, provide a link to the Creative Commons licence, and indicate if changes were made. The images or other third party material in this article are included in the article's Creative Commons licence, unless indicated otherwise in a credit line to the material. If material is not included in the article's Creative Commons licence and your intended use is not permitted by statutory regulation or exceeds the permitted use, you will need to obtain permission directly from the copyright holder. To view a copy of this licence, visit http://creativecommons.org/licenses/by/4.0/.

\section{References}

Ablamowicz R, Debowska J, Jucha M (2004) The graves of Tell elFarkha (seasons 2001-2002). In: Hendrickx S, Friedman RF, Ciałowicz KM, Chłodnicki M (eds) Egypt at Its Origins: Studies 
in Memory of Barbara Adams: Proceedings of the International Conference" Origin of the State, Predynastic and Early Dynastic Egypt," Krakow, 28 August-1st September 2002. Peeters Publishers, Leuven, Belgium, pp 399-420

Ahmed MA, Abdel Samie SG, Badawy HA (2013) Factors controlling mechanisms of groundwater salinization and hydrogeochemical processes in the Quaternary aquifer of the Eastern Nile Delta, Egypt. Environ Earth Sci 68(2):369-394

Alcock JP (2006) Food In The Ancient World. Greenwood Publishing Group, Westport, Connecticut

Al-Gamal S, El-Sayed S, Atta E (2018) Exploring surface-and groundwater interactions in East Delta Aquifer using conventional and nonconventional techniques. Journal of Applied Geology and Geophysics 6(2):48-58

Allen JP, Hekanakhte (2002) The Heqanakht Papyri. Metropolitan Museum of Art New York. New York City, New York

AlQahtani SJ, Hector MP, Liversidge HM (2010) Brief communication: the London atlas of human tooth development and eruption. Amer J Phys Anthrop 142:481-490. https://doi.org/10.1002/ajpa.21258

Ambrose SH, Krigbaum J (2003) Bone chemistry and bioarchaeology. J Anthropol Archaeol 22:193-199. https://doi.org/10.1016/S02784165(03)00033-3

Ambrose SH, Norr L (1993) Experimental evidence for the relationship of the carbon isotope ratios of whole diet and dietary protein to those of bone collagen and carbonate. In: Lambert JB, Grupe G (eds) Prehistoric Human Bone. Springer, Berlin, Germany, pp 1-37. https://doi.org/10.1007/978-3-662-02894-0_1

Arnold D, Arnold F, Allen S (1995) Canaanite Imports at Lisht, the Middle Kingdom Capital of Egypt. Ägypten und Levante / Egypt and the Levant 5:13-32

Bader B (2013) Cultural mixing in Egyptian archaeology: the 'Hyksos' as a case study. Arch Rev Cambridge 28:257-286

Bader B (2020) Tell el-Dab ${ }^{c}$ a XXIV: The Late Middle Kingdom Settlement of Area A/II A Holistic Study of Non-élite Inhabitants at Tell el-Dab ${ }^{\mathrm{c}} \mathrm{a}$, vol 1. Austrian Academy of Sciences, Vienna, Austria

Baines J (1996) Contextualizing Egyptian representations of society and ethnicity. Eisenbrauns, Winona Lake, Indiana

Balasse M, Smith AB, Ambrose SH, Leigh SR (2003) Determining sheep birth seasonality by analysis of tooth enamel oxygen isotope ratios: the Late Stone Age Site of Kasteelberg (South Africa). J Archaeol Sci 30:205-215

Beasley MM, Bartelink EJ, Taylor L, Miller RM (2014) Comparison of transmission FTIR, ATR, and DRIFT spectra: implications for assessment of bone bioapatite diagenesis. JAS 46:16-22

Beaumont J, Geber J, Powers N, Wilson A, Lee-Thorp J, Montgomery J (2013a) Victims and survivors: Stable isotopes used to identify migrants from the Great Irish Famine to 19th century London. Am J Phys Anthropol 150:87-98. https://doi.org/10.1002/ajpa.22179

Beaumont J, Gledhill A, Lee-Thorp J, Montgomery J (2013b) Childhood diet: a closer examination of the evidence from dental tissues using stable isotope analysis of incremental human dentine. Archaeometry 55:277-295. https://doi.org/10.1111/j.1475-4754.2012.00682.x

Bentley RA, Buckley HR, Spriggs M, Bedford S, Ottley CJ, Nowell GM, Macpherson CG, Pearson DG (2007) Lapita migrants in the Pacific's Oldest Cemetery: isotopic analysis at Teouma, Vanuatu. Am Antiq 72:645-656

Bietak M (1975) Tell el-Dab'a. II. Der fundort im Rahmen einer archäologisch-geographischen Untersuchung über das ägyptische Ostdelta: Untersuchungen der Zweigstelle Kairo des Osterreichischen Archäologischen Institutes I. Austrian Academy of Sciences. Vienna, Austria

Bietak M (1979) Avaris and Piramesse: archaeological exploration in the eastern Nile Delta. In: Proceedings of the British Academy London, United Kingdom. Oxford Press, pp 225-289
Bietak M (1989) Servant burials in the Middle Bronze Age culture of the eastern Nile Delta. In: Bietak M (ed) Eretz-Israel: Archaeological, Historical and Geographical Studies, vol 20. Israel Exploration Society, pp 30-43

Bietak M (1991) Tell el-Dab'a V. Ein Friedhofsbezirkder Mittleren Bronzezeitkultur mit Totentempel und Siedlungsschichten. Teil I. Untersuchungen der Zweigstelle Kairo 8, Vienna, Austria

Bietak M (1996) Avaris, The Capital of the Hyksos and Residence of the Early 18th Dynasty. Recent Excavations. London. The British Museum Press, London, United Kingdom

Bietak M (1997) The Center of Hyksos Rule: Avaris (Tell el-Daba). In: Oren ED (ed) The Hyksos: New Historical and Archaeological Perspectives. University Museum Symposium Series, Philadelphia, Pennsylvania

Bietak M (2002) Relative and absolute chronology of the Middle Bronze Age: comments on the present state of research. In: Bietak M (ed) The Middle Bronze Age in the Levant, Proceedings of an International Conference on MB II A Ceramic Materials in Vienna 24th -26 th of January 2001, Contributions to the Chronology of the Eastern Mediterranean 3. Vienna, Austria. Austrian Academy of Science, Vienna, Austria, pp 30-42

Bietak M (2009) Near Eastern sanctuaries in the eastern Nile Delta. Baal, Hors-Série 6:209-228

Bietak M (2010a) From where came the Hyksos and where did they go? In: Marée M (ed) The Second Intermediate Period (Thirteenth Seventeenth Dynasties). Uitgeveru Peeters and Departement Oosterse Studies, Leuvan, Belgium, pp 139-181

Bietak M (2010b) Houses, palaces and development of social structure in Avaris Part I. In: Bietak M, Czerny E, Forstner-Müller I (eds) Cities and Urbanism, International Workshop in November 2006 at the Austrian Academy of Sciences Vienna, Austrian Academy of Sciences, vol 60. Vienna, Austria, pp 11-68

Bietak M (2011) The aftermath of the Hyksos in Avaris. In: Sela-Sheffy R, Toury G (eds) Culture Contacts And The Making Of Cultures. Tel Aviv University, Tel Aviv, Israel, pp 19-65

Bietak M (2013a) Avaris/Tell el-Dab'a. In: Bagnall RS, Brodersen K, Champion CB, Erskine A, Huebner SR (eds) The Encyclopedia of Ancient History, vol 1. Blackwell Publishing, West Sussex, United Kingdom

Bietak M (2013b) Antagonisms in historical and radiocarbon chronology. In: Shortland AJ, Ramsey CB (eds) Radiocarbon and the chronologies of ancient Egypt. Oxbow Books, Oxford, pp 76-109

Bietak M (2016) Les sanctuaires cananéens dans le delta oriental du Nil. In: Matthie P, d'Andrea M (eds) L'archeologia del sacro e l'archeologia del culto. Sabratha, Ebla, Ardea, Lanuvio. Ebla e la Siriadall'età del bronzo all'età del ferro. Atti dei Convegni Lincei, Rome, Italy, pp 223-256

Bietak M, Czerny E, Prell S (2016) Ahmose in Avaris? In: Franzmeier H, Rehren T, RSchultz (eds) Mit archäologischen Schichten Geschichte schreiben: Festschrift für Edgar B. Pusch zum 70. Geburtstag. Gebrüder Gerstenberg, Hildesheim, Germany, pp 79-93

Bocherens H, Drucker D (2003) Trophic level isotopic enrichment of carbon and nitrogen in bone collagen: case studies from recent and ancient terrestrial ecosystems. Int J Osteoarchaeol 13:46-53

Boessneck J, von den Driesch A (1992) Tell El-Dab'a VII : Tiere Und Historische Umwelt Im Nordost-Delta Im 2. Jahrtausend V.Chr. Anhand Der Knochenfunde Der Ausgrabungen 1975-1986. Austrian Academy of Sciences Press, Vienna, Austria

Bowen GJ (2018) The online isotopes in precipitation calculator, version 3.1. University of Utah. http://www.waterisotopes.org Accessed 19 April 2019

Bowen GJ, West JB, Miller CC, Zhao L, Zhang T (2013) IsoMAP: Isoscapes Modeling. Prediction, Analysis and version 1.0

Brettell R, Montgomery J, Evans J (2012) Brewing and stewing: the effect of culturally mediated behaviour on the oxygen isotope 
composition of ingested fluids and the implications for human provenance studies. J Anal At Spectrom 27:778-785

Brickley M, McKinley JI (eds) (2004) Guidelines to the Standards for Recording Human Remains vol IFA Paper No. 7, IFA Technical Paper no, vol 7. BABAO, Reading, UK

Brown TA, Nelson DE, Vogel JS, Southon JR (1988) Improved Collagen Extraction by Modified Longin Method. Radiocarbon 30 (2):171177

Bryant JD, Froelich PN (1995) A model of oxygen isotope fractionation in body water of large mammals. Geochim Cosmochim Acta 59: 4523-4537

Buikstra JE, Ubelaker DH (1994) Standards for data collection from human skeletal remains. Arkansas Archaeological Survey, Fayetteville

Buzon MR, Bowen GJ (2010) Oxygen and carbon isotope analysis of human tooth enamel from the New Kingdom site of Tombos in Nubia. Archaeom 52:855-868. https://doi.org/10.1111/j.14754754.2009.00503.x

Buzon MR, Simonetti A, Creaser RA (2007) Migration in the Nile Valley during the New Kingdom period: a preliminary strontium isotope study. J Archaeol Sci 34:1391-1401. https://doi.org/10.1016/j.jas. 2006.10.029

Caracuta V, Fiorentino G, Davoli P, Bagnall R (2018) Farming and Trade in Amheida/Trimithis (Dakhla Oasis, Egypt): New Insights from Archaeobotanical Analysis. In: Mercuri AM, D'Andrea AC, Fornaciari R, Höhn A (eds) Plants and People in the African Past: Progress in African Archaeobotany. Springer International Publishing, Cham, Switzerland, pp 57-75. https://doi.org/10.1007/ 978-3-319-89839-1 4

Castel G (1988) Les mines de galène pharaoniques du Gebel el Zeit. Bulletin of the Société Française d'Égyptologie 112:37-53

Castel G, Soukiassian G, Pouit G (1999) Gebel Zeit. In: Bard KA (ed) Encyclopedia of the Archaeology of Ancient Egypt. Routledge, London, UK, pp 334-338

Chenery CA, Müldner G, Evans J, Eckardt H, Lewis M (2010) Strontium and stable isotope evidence for diet and mobility in Roman Gloucester, UK. J Archaeol Sci 37:150-163

Chenery CA, Pashley V, Lamb AL, Sloane HJ, Evans JA (2012) The oxygen isotope relationship between the phosphate and structural carbonate fractions of human bioapatite. Rapid Commun Mass Spectrom 26:309-319

Cheung C, Jing Z, Tang J, Weston DA, Richards MP (2017) Diets, social roles, and geographical origins of sacrificial victims at the royal cemetery at Yinxu, Shang China: New evidence from stable carbon, nitrogen, and sulfur isotope analysis. J Anthropol Archaeol 48:28 45. https://doi.org/10.1016/j.jaa.2017.05.006

Cockerton H, Street-Perrott F, Leng M, Barker P, Horstwood M, Pashley V (2013) Stable-isotope (H, O, and Si) evidence for seasonal variations in hydrology and Si cycling from modern waters in the Nile Basin: implications for interpreting the Quaternary record. Quat Sci Rev 66:4-21

Cohen SL (2012) Weaponry and warrior burials: Patterns of disposal and social change in the southern Levant. In: The 7th International Congress On The Archaeology Of The Ancient Near East. pp 307319

Cohen SL (2018) Canaanites, chronologies, and connections: the relationship of Middle Bronze IIA Canaan to Middle Kingdom Egypt. Brill, Leiden, Netherlands

Commendador AS, Finney BP, Fuller BT, Tromp M, Dudgeon JV (2019) Multiproxy isotopic analyses of human skeletal material from Rapa Nui: Evaluating the evidence from carbonates, bulk collagen, and amino acids. Am J Phys Anthropol 169:714-729. https://doi.org/10. 1002/ajpa.23851

Crawford PL (2007) Beyond paper: use of plants of the Cyperaceae family in ancient Egypt. In: Cappers R (ed) Fields of Change: progress in African Archaeology, vol 5. Groningen, Groningen, the Netherlands, pp 105-113

Czerny E (2001) Ein Früher Beleg Für ḥwt-w rt Auf Einem Siegelabdruck Aus Tell El-Dab a. Ägypten und Levante/Egypt and the Levant 11:13-26

Czerny E (2015) Tell el-Dab a XXII - "Der Mund der beiden Wege“ Die Siedlung und der Tempelbezirk des Mittleren Reiches von Ezbet Ruschdi. Denkschriften der Gesamtakademie, vol 77. Austrian Academy of Sciences Press, Vienna, Austria

Czerny E, von den Driesch A (1999) Tell el-Dab'a IC. Eine Plansiedlung des frühen mittleren Reiches Austrian Academy of Sciences. Austria, Vienna

Darby WJ, Ghalioungui P, Grivetti L (1977) Food: the gift of Osiris. Academic Press, London, United Kingdom

Daux V, Lécuyer C, Héran MA, Amiot R, Simon L, Fourel F, Martineau F, Lynnerup N, Reychler H, Escarguel G (2008) Oxygen isotope fractionation between human phosphate and water revisited. J Hum Evol 55:1138-1147

David AR (1999) Handbook to life in ancient Egypt. Oxford University Press, Oxford, United Kingdom

DeNiro MJ, Epstein S (1978) Influence of diet on the distribution of carbon isotopes in animals. Geochim Cosmochim Acta 42:495-506

Dillery J (1999) The First Egyptian Narrative History: Manetho and Greek Historiography. ZPE 127:93-116

Dondero M, Van Hook J, Frisco M, Martin M (2018) Dietary acculturation and dietary quality among Mexican children of immigrants: the role of food settings. J Health Soc Behav 59:464-488

Dorner J (1994) Die Rekonstruktion einer pharaonischen Flusslandschaft. Mitteilungen der Anthropologischen Gesellschaft in Wien 123/124 401-406

Dupras LT (1999) Dining in the Dakhleh Oasis, Egypt: Determination of diet using documents and stable isotope analysis. McMaster University

Eerkens JW, Voogt A, Dupras TL, Francigny V, Greenwald AM (2018) Early childhood life history on the Nile: $\delta^{13} \mathrm{C}$ and $\delta^{15} \mathrm{~N}$ in serial samples of permanent first molars in an Elite Meroitic Population from Sai Island, Sudan. Int J Osteoarchaeol 28:552-562. https://doi. org/10.1002/oa.2679

Eissa M, Ali M, Zaghlool E, Stash OS (2019) Hydrochemical and stable isotopes indicators for detecting sources of groundwater contamination close to Bahr El-Baqar drain, eastern Nile Delta, Egypt. Water Science 33(1):54-64

Fahmy AG-E-D, Kawai N, Yoshimura S (2013) Archaeobotany of two Middle Kingdom cult chambers at Northwest Saqqara, Egypt. In: Fuller DQ, Murray M-A, Stevens CJ, Nixon S (eds) Archaeology of African Plant Use. Routledge, Walnut Creek, California, pp 141-149

Farag MA, Elmassry MM, Baba M, Friedman R (2019) Revealing the constituents of Egypt's oldest beer using infrared and mass spectrometry. Sci Rep 9:16199. https://doi.org/10.1038/s41598-01952877-0

Forstner-Müller I (2007) The colonization/urbanization of the Tell Area $\mathrm{A} / \mathrm{II}$ at Tell el-Dab'a and its chronological implications. Ägypten und Levante/Egypt and the Levant, vol 17:83-95

Forstner-Müller I (2008) Tell el-Dab'a XVI, Die Gräber des Areals A/Il von Tell el-Dab'a. Austrian Academy of Sciences, Vienna, Austria

Forstner-Müller I (2010) Tombs and burial customs at Tell el-Dab'a during the late Middle Kingdom and Second Intermediate Period. In: Marèe $M$ (ed) The Second Intermediate Period (ThirteenthSeventeenth Dynasties). Current Research, Future Prospects. OLA, Leuven, Belgium, pp 127-138

France CAM, Sugiyama N, Aguayo E (2020) Establishing a preservation index for bone, dentin, and enamel bioapatite mineral using ATRFTIR. J Archaeol Sci Rep 33:102551

Fry B, Lutes R, Northam M, Parker PL, Ogden J (1982) A ${ }^{13} \mathrm{C} /{ }^{12} \mathrm{C}$ comparison of food webs in Caribbean seagrass meadows and coral 
reefs. Aquat Bot 14:389-398. https://doi.org/10.1016/03043770(82)90112-7

Fuller DQ (2014) Agricultural innovation and state collapse in Meroitic Nubia. In: Stevens CJ, Nixon S, Murray M-A, Fuller DQ (eds) Archaeology of African plant use. UCL Institute of Archaeology Publications, London, pp 165-177

Geirnaert W, Laeven MP (1992) Composition and history of ground water in the western Nile Delta. J Hydrol 138:169-189. https://doi. org/10.1016/0022-1694(92)90163-P

Gomaah M, Meixner T, Korany EA, Garamoon H, Gomaa MA (2016) Identifying the sources and geochemical evolution of groundwater using stable isotopes and hydrogeochemistry in the Quaternary aquifer in the area between Ismailia and El Kassara canals, Northeastern Egypt. Arab J Geosci 9(6):437

Gregoricka LA, Ullinger J, Sheridan SG (2020) Status, kinship, and place of burial at Early Bronze Age Bab adh-Dhra': a biogeochemical comparison of charnel house human remains. Am J Phys Anthropol 171:319-335. https://doi.org/10.1002/ajpa.23982

Hamza MS, Aly AIM, Swailem FM, Nada A (1987) Environmentally stable isotopes and groundwater recharge in the eastern Nile delta. International Journal of Water Resources Development 3(4):228 232

Harrington N, Draycott CM, Stamatopoulou M (2016) The Eighteenth Dynasty Egyptian banquet: ideals and realities. In: Catherine Mary Draycott MS (ed) Dining and Death: Interdisciplinary Perspectives on the "Funerary Banquet" in Ancient Art. Burial and Belief. Peeters, Leuven, Belgium, pp 129-172

Hassan HB, El Rayan RA, Huissen RA (2020) Surface -Groundwater Interaction in the Area between El-Timsah Lake and Ismailia Canal Using Hydrochemical and Isotopic Techniques. Arab Journal of Nuclear Sciences and Applications 53(3):276-290

Hedges REM, Clement JG, Thomas CDL, O'Connell TC (2007) Collagen turnover in the adult femoral mid-shaft: modeled from anthropogenic radiocarbon tracer measurements. Am J Phys Anthropol 133:808-816

Hillson S (1996) Dental Anthropology. Cambridge University Press, Cambridge, United Kingdom

Hobson KA, Clark RG (1992) Assessing avian diets using stable isotopes II: factors influencing diet-tissue fractionation. Condor 94:189-197

Hoefs J (2009) Stable Isotope Geochemistry, 6th edn. Springer-Verlag, Berlin, Germany

Höflmayer F (2019) The Expulsion of the Hyksos and the End of the Middle Bronze Age: a reassessment in light of recent chronological research. Journal of Ancient Egyptian Interconnections 21:20-30

Hollund HI, Ariese F, Fernandes R, Jans MME, Kars H (2013) Testing an alternative high-throughput tool for investigating bone diagenesis: FTIR in attenuated total reflection (ATR) mode. Archaeometry 55(3):507-532

Hoppe KA, Koch PL, Furutani TT (2003) Assessing the preservation of biogenic strontium in fossil bones and tooth enamel. Int $\mathrm{J}$ Osteoarchaeol 13(1-2):20-28

Jim S, Ambrose SH, Evershed RP (2004) Stable carbon isotopic evidence for differences in the dietary origin of bone cholesterol, collagen and apatite: implications for their use in palaeodietary reconstruction. Geochim Cosmochim Acta 68:61-72. https://doi.org/10.1016/ S0016-7037(03)00216-3

Josephus F (1849) The works of Flavius Josephus... Translated by William Whiston. William Milner, Edinburgh, Scotland

Katzenberg MA (2008) Stable isotope analysis: a tool for studying past diet, demography, and life history. In: Katzenberg MA, Saunders SR (eds) Biological Anthropology of the Human Skeleton. John Wiley \& Sons, Inc., Hoboken, New Jersey, pp 411-441. https://doi.org/10. 1002/9780470245842.ch13

Katzenberg MA, Lovell NC (1999) Stable isotope variation in pathological bone. Int J Osteoarchaeol 9:316-324
Keegan WF, DeNiro MJ (1988) Stable carbon- and nitrogen-isotope ratios of bone collagen used to study coral-reef and terrestrial components of prehistoric Bahamian diet. Amer Ant 53:320-336. https:// doi.org/10.2307/281022

Kemp BJ, Samuel D, Luff R (1994) Food for an Egyptian city: Tell elAmarna. In: Luff RM (ed) Rowley-Conwy P (eds) Whither environmental archaeology? vol 38. Oxbow, Oxford, United Kingdom, pp $133-170$

King CL, Bentley RA, Tayles N, Viðarsdóttir US, Nowell G, Macpherson CG (2013) Moving peoples, changing diets: isotopic differences highlight migration and subsistence changes in the Upper Mun River Valley, Thailand. J Archaeol Sci 40:1681-1688. https://doi.org/10.1016/j.jas.2012.11.013

Kutschera W, Bietak M, Wild EM, Ramsey CB, Dee M, Golser R, Kopetzky K, Stadler P, Steier P, Thanheiser U, Weninger F (2012) The chronology of Tell el-Daba: a crucial meeting point of ${ }^{14} \mathrm{C}$ dating, archaeology, and Egyptology in the $2^{\text {nd }}$ millennium $\mathrm{BC}$. Radiocarbon 54:407-422

Lamb AL, Evans JE, Buckley R, Appleby J (2014) Multi-isotope analysis demonstrates significant lifestyle changes in King Richard III. J Archaeol Sci 50:559-565. https://doi.org/10.1016/j.jas.2014.06.021

Laneri N (2007) An archaeology of funerary rituals. Performing Death: Social Analyses Of Funerary Traditions In The Ancient Near East And Mediterranean, vol 3. The University of Chicago, Chicago, Illinois

Lee-Thorp JA, Sealy JC, van der Merwe NJ (1989) Stable carbon isotope ratio differences between bone collagen and bone apatite, and their relationship to diet. J Archaeol Sci 16:585-599

Li M-R, Wedin DA, Tieszen LL (1999) $\mathrm{C}_{3}$ and $\mathrm{C}_{4}$ photosynthesis in Cyperus (Cyperaceae) in temperate eastern North America. Can J Bot 77:209-218

Longin (1971) New Method of Collagen Extraction for Radiocarbon Dating. Nature 230 (5291):241-242

Longinelli A (1984) Oxygen isotopes in mammal bone phosphate: a new tool for paleohydrological and paleoclimatological research? Geochim Cosmochim Acta 48:385-390

Luz B, Kolodny Y (1989) Oxygen isotope variation in bone phosphate. Appl Geochem 4:317-323

Marcus ES (1998) Maritime trade in the southern Levant from earliest times through the Middle Bronze IIA period. University of Oxford

Marcus ES (2007) Amenemhet Ii And The Sea: Maritime Aspects Of The Mit Rahina (Memphis) Inscription. Ägypten und Levante / Egypt and the Levant 17:137-190

Marshall JD, Brooks JR, Lajtha K (2007) Sources of variation in the stable isotopic composition of plants. In: Michener R, Lajtha $\mathrm{K}$ (eds) Stable Isotopes in Ecology and Environmental Science. Blackwell Publishing Ltd, Malden, Maryland, pp 22-60

Minagawa M, Wada E (1984) Stepwise enrichment of ${ }^{15} \mathrm{~N}$ along food chains: further evidence and the relation between $\delta^{15} \mathrm{~N}$ and animal age. Geochim Cosmochim Acta 48:1135-1140. https://doi.org/10. 1016/0016-7037(84)90204-7

Moens M-F, Wetterstrom W (1988) The Agricultural Economy of an Old Kingdom Town in Egypt's West Delta: Insights from the Plant Remains. Journal Near East Stud 47:159-173. https://doi.org/10. $1086 / 373282$

Morand N (2020) The exploitation of molluscs and other invertebrates in Alexandria (Egypt) from the Hellenistic period to Late Antiquity: food, usage, and trade. Anthropozoologica 55(1-20):20

Mourad A-L (2015) Rise of the Hyksos: Egypt and the Levant from the Middle Kingdom to the Early Second Intermediate Period. Archaeopress, Oxford, United Kingdom

Müldner G, Chenery C, Eckardt H (2011) The 'Headless Romans': multiisotope investigations of an unusual burial ground from Roman Britain. J Archaeol Sci 38:280-290

Murray MA (1999) Wine Production and Consumption in Pharaonic Egypt. In: van der Veen M (ed) The Exploitation of Plant 
Resources in Ancient Africa. Springer US, Boston, Maryland, pp 149-169. https://doi.org/10.1007/978-1-4757-6730-8_13

Murray M-A (2000) Fruits, vegetables, pulses, and condiments. In: Nicholson PT, Shaw I (eds) Ancient Egyptian Materials and Technology. Cambridge University Press, Cambridge, UK, pp 609-655

Negbi M (1992) A sweetmeat plant, a perfume plant and their weedy relatives: a chapter in the history of Cyperus esculentus $L$. and $C$. rotundus $L$. Econ Bot 46:64-71

O'Connor D (1997) The Hyksos Period in Egypt. In: Oren E (ed) The Hyksos: New historical and archaeological perspectives, The University Museum, vol 96. University of Pennsylvania, Philadelphia, Pennsylvania, pp 45-67

O'Connell TC, Kneale CJ, Tasevska N, Kuhnle GGC (2012) The dietbody offset in human nitrogen isotopic values: A controlled dietary study. Am J Phys Anthropol 149:426-434

Passey BH, Robinson TF, Ayliffe LK, Cerling TE, Sponheimer M, Dearing MD, Roeder BL, Ehleringer JR (2005) Carbon isotope fractionation between diet, breath $\mathrm{CO}_{2}$, and bioapatite in different mammals. JArch Sci 32:1459-1470. https://doi.org/10.1016/j.jas. 2005.03.015

Pearson CL et al (2018) Annual radiocarbon record indicates 16th century BCE date for the Thera eruption. Sci Adv 4:eaar8241

Pederzani S, Britton K (2018) Oxygen isotopes in bioarchaeology: principles and applications, challenges and opportunities. Earth-Sci Rev 188:77-107. https://doi.org/10.1016/j.earscirev.2018.11.005

Perkins MJ, McDonald RA, van Veen FJF, Kelly SD, Rees G, Bearhop S (2014) Application of nitrogen and carbon stable isotopes $\left(\delta^{15} \mathrm{~N}\right.$ and $\left.\delta^{13} \mathrm{C}\right)$ to quantify food chain length and trophic structure. PLoS One 9:e93281

Peters BA, Yi SS, Beasley JM, Cobbs EN, Choi HS, Beggs DB, Hayes RB, Ahn J (2020) US nativity and dietary acculturation impact the gut microbiome in a diverse US population. ISME J 14:1639-1650. https://doi.org/10.1038/s41396-020-0630-6

Philip G (1989) Metal weapons of the Early and Middle Bronze Ages in Syria-Palestine vol 526. BAR, Oxford, United Kingdom

Philip G (1995) Warrior burials in the ancient Near-Eastern Bronze Age: the evidence from Mesopotamia, western Iran and Syria-Palestine. In: Campbell S, Green A (eds) The Archaeology of Death in the Ancient Near East. Oxbow Books, Oxford, UK, pp 140-154

Philip G (2006) Tell el-Dab'a XV: metalwork and metalworking evidence of the late Middle Kingdom and second intermediate period vol 26. Austrian Academy of Sciences, Vienna, Austria

Plomp E, von Holstein ICC, Kootker LM, Verdegaal-Warmerdam SJA, Forouzanfar T, Davies GR (2020) Strontium, oxygen, and carbon isotope variation in modern human dental enamel. Am J Phys Anthropol 172:586-604. https://doi.org/10.1002/ajpa.24059

Prell S (2019a) Burial Customs as Cultural Marker: a 'Global' Approach. In: Bietak M, Prell S (eds) The Enigma of the Hyksos, Harrassowitz Verlag, vol 1. Wiesbaden, Germany, pp 125-147

Prell S (2019b) A Ride to the Netherworld: Bronze Age Equid Burials in the Fertile Crescent. In: Bietak M, Prell S (eds) The Enigma of the Hyksos, Harrassowitz Verlag, vol 1. Wiesbaden, Germany, pp $107-123$

Prell S, Rahmstorf L (2019) Im Jenseits Handel betreiben. Areal A/I in Tell el-Dab a/Avaris - die hyksoszeitlichen Schichten und ein reich ausgestattetes Grab mit Feingewichten In: Bietak M, Prell S (eds) The Enigma of the Hyksos, vol 1. Harrassowiz Verlag, Wiesbaden, Germany, pp 165-197

Prowse TL, Schwarcz HP, Garnsey P, Knyf M, Macchiarelli R, Bondioli L (2007) Isotopic evidence for age-related immigration to imperial Rome. Am J Phys Anthropol 132:510-519

$\mathrm{R}$ Core Team (2000) R language definition.

Ramírez AS, Golash-Boza T, Unger JB, Baezconde-Garbanati L (2018) Questioning the dietary acculturation paradox: a mixed-methods study of the relationship between food and ethnic identity in a group of Mexican-American women. J Acad Nutr Diet 118:431-439. https://doi.org/10.1016/j.jand.2017.10.008

Redford DB (1970) The Hyksos invasion in history and tradition. Orientalia 39:1-51

Richards MP, Hedges REM (1999) Stable isotope evidence for similarities in the types of marine foods used by Late Mesolithic humans at sites along the Atlantic Coast of Europe. J Archaeol Sci 26:717-722

Riehl S (2019) Barley in Archaeology and Early History. Oxford University Press, Oxford, United Kingdom. https://doi.org/10. 1093/acrefore/9780199389414.013.219

Said R (2017) Geomorphology. In: Said R (ed) The geology of Egypt. Routledge, London

Samuel D (1996) Archaeology of Ancient Egyptian Beer. J Am Soc Brew Chem 54:3-12. https://doi.org/10.1094/ASBCJ-54-0003

Satia JA (2010) Dietary acculturation and the nutrition transition: an overview. Appl Physiol Nutr Metab 35:219-223

Satia-Abouta J, Patterson RE, Neuhouser ML, Elder J (2002) Dietary acculturation: applications to nutrition research and dietetics. J Am Diet Assoc 102:1105-1118. https://doi.org/10.1016/S00028223(02)90247-6

Schiestl R (2008) Tomb Types and Layout of a Middle Bronze IIA cemetery at Tell el-Dab ${ }^{\mathrm{c}} \mathrm{a}$, area F/I: Egyptian and Non-Egyptian features. In: Bietak M, Czerny E (eds) The Bronze Age in the Lebanon: Studies on the Archaeology and Chronology of Lebanon, Syria and Egypt, Contributions to the Chronology of the Eastern Mediterranean, Austrian Academy of Sciences, vol 17. Vienna, Austria, pp 243-256

Schiestl R (2009) Die Palastnekropole von Tell el-Dab ${ }^{\mathrm{c}} \mathrm{a}$. Die Gräber des Areals F/I der Straten d/2 und d/1 vol XVIII. Austrian Academy of Sciences, Vienna, Austria

Schildgen TF, Cosentino D, Frijia G, Castorina F, Dudas FÖ, Iadanza A, Sampalmieri G, Cipollari P, Caruso A, Bowring SA, Strecker MR (2014) Sea level and climate forcing of the Sr isotope composition of late Miocene Mediterranean marine basins. Geochem Geophys Geosyst 15(7):2964-2983

Schoeninger MJ (2010) Diet reconstruction and ecology using stable isotope ratios. In: Larsen CS (ed) A Companion to Biological Anthropology. Wiley-Blackwell, West Sussex, United Kingdom, pp 445-464. https://doi.org/10.1002/9781444320039.ch25

Schoeninger MJ, DeNiro MJ (1984) Nitrogen and carbon isotopic composition of bone collagen from marine and terrestrial animals. Geochim Cosmochim Acta 48:625-639

Schrader SA, Buzon MR, Corcoran L, Simonetti A (2019) Intraregional ${ }^{87} \mathrm{Sr} /{ }^{86} \mathrm{Sr}$ variation in Nubia: New insights from the Third Cataract. J Archaeol Sci Rep 24:373-379

Schroeder H, O'Connell TC, Evans JA, Shuler KA, Hedges REM (2009) Trans-Atlantic slavery: isotopic evidence for forced migration to Barbados. Am J Phys Anthropol 139:547-557

Sharp ZD (2017) Principles of Stable Isotope Geochemistry, Second Edition. Published Online. https://doi.org/10.5072/FK2GB24S9F

Spallek J, Zeeb H, Razum O (2011) What do we have to know from migrants' past exposures to understand their health status? a life course approach. Emerg Themes Epidemiol 8:6. https://doi.org/10. 1186/1742-7622-8-6

Stantis C, Kinaston RL, Richards MP, Davidson JM, Buckley HR (2015) Assessing human diet and movement in the Tongan Maritime Chiefdom using isotopic analyses. PLoS One 10:e123156

Stantis C, Buckley HR, Kinaston RL, Nunn PD, Jaouen K, Richards MP (2016) Isotopic evidence of human mobility and diet in a prehistoric/ protohistoric Fijian coastal environment (c. 750-150 BP). Am J Phys Anthropol 159:478-495. https://doi.org/10.1002/ajpa.22884

Stantis C, Nowell GM, Prell S, Schutkowski H (2019) Animal proxies to characterize the strontium biosphere in the northeastern Nile Delta. Bioarchaeology of the Near East 13:1-13

Stantis C, Kharobi A, Maaranen N, Nowell GM, Bietak M, Prell S, Schutkowski H (2020) Who were the Hyksos? Challenging 
traditional narratives using strontium isotope $\left({ }^{87} \mathrm{Sr} /{ }^{86} \mathrm{Sr}\right)$ analysis of human remains from ancient Egypt. PLoS One 15:e0235414. https://doi.org/10.1371/journal.pone.0235414

Tieszen LL, Fagre T (1993) Effect of diet quality and composition on the isotopic composition of respiratory $\mathrm{CO}_{2}$, bone collagen, bioapatite, and soft tissues. In: Lambert JB, Grupe G (eds) Prehistoric Human Bone: Archaeology at the Molecular Level. Springer, Berlin Heidelberg, Berlin, Germany, pp 121-155. https://doi.org/10.1007/ 978-3-662-02894-0 5

Tieszen LL, Boutton TW, Tesdahl K, Slade NA (1983) Fractionation and turnover of stable carbon isotopes in animal tissues: implications for $\delta^{13} \mathrm{C}$ analysis of diet. Oecologia 57:32-37

Trickett MA, Budd P, Montgomery J, Evans J (2003) An assessment of solubility profiling as a decontamination procedure for the $87 \mathrm{Sr} /$ $86 \mathrm{Sr}$ analysis of archaeological human skeletal tissue. Appl Geochem 18(5):653-658

Tronchère H, Goiran J-P, Schmitt L, Preusser F, Bietak, M, ForstnerMüller I, \& Callot Y (2012) Geoarchaeology of an ancient fluvial harbour: Avaris and the Pelusiac branch (Nile River, Egypt). Géomorphologie: relief, processus, environnement 18(1):23-36

Trueman CN, Privat K, Field J (2008) Why do crystallinity values fail to predict the extent of diagenetic alteration of bone mineral?
Palaeogeography, Palaeoclimatology. Palaeoecology 266(3): $160-167$

Tuross N, Reynard LM, Harvey E, Coppa A, McCormick M (2017) Human skeletal development and feeding behavior: the impact on oxygen isotopes. Archaeol Anthropol Sci 9(7):1453-1459. https:// doi.org/10.1007/s12520-017-0486-5

van den Brink EC (1982) Tombs and burial customs at Tell el-Dab'a. Institute für Afrikanistik und Ägyptologie der Universitat Wien, Vienna, Austria

Wapnish P (1997) Middle Bronze equid burials at Tell Jemmeh and a reexamination of a purportedly Hyksos practice. In: Oren E (ed) The Hyksos: New historical and archaeological perspectives. University of Pennsylvania Museum, Philadelphia, Pennsylvania, pp 335-367

Winkler E-M, Wilfing H (1991) Tell El-Dab ${ }^{c}$ a IV: Anthropologische Untersuchungen an den Skelettresten der Kampagnen 1966-1969, 1975-80, 1985. Austrian Academy of Sciences, Vienna, Austria

Publisher's note Springer Nature remains neutral with regard to jurisdictional claims in published maps and institutional affiliations. 